\title{
Geomorphological Evidence of Active Faulting in Low Seismicity Regions-Examples From the Valley of Gobi Lakes, Southern Mongolia
}

\author{
Jorien L. N. van der Wal ${ }^{1 *}$, V. C. Nottebaum ${ }^{2}$, G. Stauch ${ }^{2}$, S. A. Binnie ${ }^{3}$, O. Batkhishig ${ }^{4}$, \\ F. Lehmkuhl ${ }^{2}$ and K. Reicherter ${ }^{1}$ \\ ${ }^{1}$ Institute of Neotectonics and Natural Hazards, RWTH Aachen University, Aachen, Germany, ${ }^{2}$ Chair of Physical Geography and \\ Geoecology, RWTH Aachen University, Aachen, Germany, ${ }^{3}$ Institute of Geology and Mineralogy, University of Cologne, Cologne, \\ Germany, ${ }^{4}$ Institute of Geography, Geoecology, Mongolian Academy of Sciences, Ulaanbaatar, Mongolia
}

\section{OPEN ACCESS}

Edited by:

Ramon Arrowsmith, Arizona State University, United States

Reviewed by:

R. Jayangonda Perumal, Central University of Tamil Nadu, India Jian-Cheng Lee,

Academia Sinica, Taiwan

*Correspondence:

Jorien L. N. van der Wal j.vanderwal@nug.rwth-aachen.de

Specialty section:

This article was submitted to Structural Geology and Tectonics,

a section of the journal

Frontiers in Earth Science

Received: 31 July 2020 Accepted: 16 December 2020 Published: 26 January 2021

Citation:

van der Wal JLN, Nottebaum VC, Stauch G, Binnie SA, Batkhishig O, Lehmkuhl F and Reicherter K (2021) Geomorphological Evidence of Active Faulting in Low Seismicity Regions - Examples From the Valley of

Gobi Lakes, Southern Mongolia.

Front. Earth Sci. 8:589814.

doi: 10.3389/feart.2020.589814
Active intraplate deformation as a far-field effect of the India-Eurasia convergence has led to four Mw 8 earthquakes in western and southern Mongolia in the past century. Palaeoseismological and morphotectonic studies have shown that these earthquakes are characteristic events along transpressive fault systems with cumulative offsets. The tectonically active Gobi Altai and Hangay mountains are separated by the seismically quiescent Valley of Gobi Lakes, which consists of major perennial rivers draining into endorheic lakes. Despite the scarcity of recorded earthquakes, Quaternary deposits in the Valley of Gobi Lakes are crosscut by multiple fault scarps with significant, landscape-altering displacements. To assess past earthquakes and the potential seismic hazard of this area, we apply remote sensing, tectono-morphometric techniques and cosmogenic nuclide dating to estimate the amount of deformation the faults in the Valley of Gobi Lakes are accommodating, and to determine the effect of these faults on local landscape evolution. The Tuyn Gol (gol = Mongolian for river) is crosscut by four E-W to NE-SW trending fault scarps that display variable fault kinematics due to scarp orientation differences relative to a stable NE-SW principle stress direction. Mapping of the $>40-90 \mathrm{~km}$ long Valley of Gobi Lake faults shows that they can accommodate $\mathrm{M} \sim 7$ earthquakes. Offset measurements of the Tuyn Gol deposits allow Middle Pleistocene to modern vertical slip rate estimates and $\mathrm{M} \sim 7$ earthquake recurrence intervals of $0.012 \pm 0.007-0.13 \pm 0.07 \mathrm{~mm} / \mathrm{yr}$ and $5.24 \pm 2.61-81.57 \pm 46.05 \mathrm{kyr}$, respectively. Cumulative vertical displacement amounts to $0.27 \pm 0.08 \mathrm{~mm} / \mathrm{yr}$, which is similar to that of major tectonic structures such as the Bogd fault in the Gobi Altai. This implies that the total active deformation accommodated by southern Mongolian faults may be larger than previously expected and distributed across more faults between the Hangay and the (Gobi) Altai mountain ranges. Geomorphological observations and surface exposure dating indicate that the Tuyn Gol drainage system developed over four to five $100 \mathrm{kyr}$ climate cycles, during which active deformation played an important role in drainage reorganization. Our results demonstrate the dominant role of tectonics on local landscape dynamics, indicating the importance of studying regional geomorphology to adequately estimate the earthquake potential of faults that were considered inactive.

Keywords: active tectonics, tectonic geomorphology (morphotectonics), alluvial fans, landscape evolution, Valley of Gobi Lakes, Gobi Altai, Mongolia 


\section{INTRODUCTION}

Palaeoseismological investigations typically focus on areas that have experienced instrumental or historical (surface-rupturing) earthquakes in the past 100 years (e.g. McCalpin, 2009). In remote, sparsely populated areas, these studies consist of the investigation of sedimentary deposits and geomorphological features that have been preserved in spite of erosional and climatic processes overprinting them (e.g., Burbank and Anderson, 2001; Bull, 2007). In (semi-)arid environments tectonic imprints on geomorphology are often well preserved (e.g., Arrowsmith and Zielke, 2009; Zielke et al., 2015), allowing for investigations further back in time than would be possible in, for example, temperate and humid climates. In slowly deforming continental interiors, such an expansion of the tectonic record is essential for the identification of palaeo-earthquakes with recurrence intervals that exceed the instrumental record (e.g., Walker et al., 2008; Clark et al., 2015; Landgraf et al., 2015). The preservation of fault scarps in (semi-)arid regions allows for tectonic activity to be studied within the context of climatic variations, thus providing insight into the balance between long-term climatic and tectonic processes. Bridging the gap between long-term tectonic processes (i.e., uplift and mountain building processes) and the instrumental or historical seismic record is especially essential in slow-slip regions that may be surrounded by instrumental seismicity but which are themselves considered seismically quiescent. In this contribution, we evaluate regional fluvial geomorphology in southern Mongolia to determine the Pleistocene to modern tectonic activity of seismically quiescent fault scarps. We determine the earthquake potential of the faults in the Valley of Gobi Lakes and analyze their role in the regional strain field.

The Valley of Gobi Lakes (VGL) in southern Mongolia is a tectonically quiescent foreland basin that is located between the seismically active Gobi Altai and Hangay strike-slip regimes (see Figure 1; e.g., Erdenetsogt et al., 2009; Lehmkuhl et al., 2018). The Quaternary alluvial fans of major rivers draining south from the Hangay into endorheic lakes display multiple terraces and, in some cases, as with the deposits of the Tuyn Gol (TG), are crosscut by semi-parallel $\sim \mathrm{E}-\mathrm{W}$ trending fault scarps (Mosionzd et al., 1988; Cunningham, 2013). The historical record of earthquakes in Mongolia is scarce (e.g., Dugarmaa et al., 2003; Walker et al., 2008) and the instrumental record of the VGL only shows minor local $M \sim 4$ earthquakes in the past 100 years (Figure 1), which are unlikely to have contributed to the surface

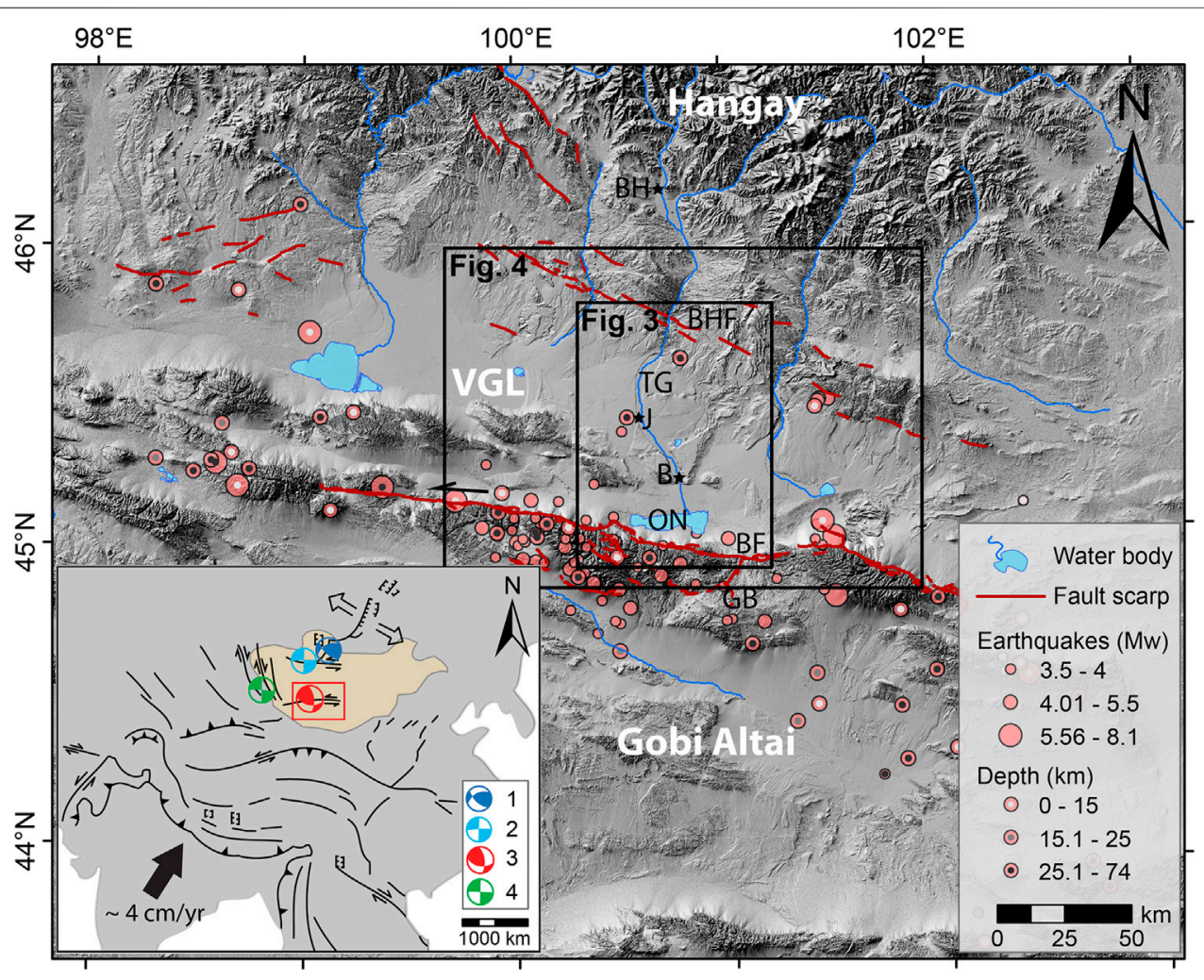

FIGURE 1 | Regional tectonic setting of the VGL located between the Gobi Altai and the Hangay. Inset shows tectonic setting within the Asian continent (yellow shape is Mongolia), earthquake focal mechanisms correspond to the four major earthquakes in the 20th century (1) Tsetserleg: Mw = 8.0, 1905; 2) Bulnay: Mw = 8.3, 1905; 3) Fuyun: Ms = 7.9, 1931 and 4) Gobi Altai: Mw = 8.1, 1957). Earthquake data from USGS and Munkhuu (2018); Bogd fault data from Kurushin et al. (1997). Abbreviations: TG, Tuyn Gol; ON, Orog Nuur; BH, Bayankhongor; J, Jinst; B, Bogd; GB, Gurvan bogd; BF, Bogd fault; BHF, Bayankhongor fault. 
displacements visible today. We aim to identify the earthquake potential of the VGL faults (i.e., their potential magnitude, recurrence interval and slip rates), and determine how much (previously considered aseismic) slip they are accommodating, relative to the major fault systems in the Gobi Altai and Hangay. To do this, a full understanding of the processes that shaped the VGL is required, including a qualitative assessment of landscape evolution during the Late Pleistocene and Holocene. Regional aridity in southern Mongolia aids the preservation of cumulative surface displacements in the landscape (e.g., Baljinnyam et al., 1993; Vassallo et al., 2007; Walker et al., 2006; Walker et al., 2008), which makes this a suitable area to study the long-term (Pleistocene to modern) interplay of tectonic and geomorphological processes. The study area serves as an example for the expansion of spatial and temporal scales for studies aiming to understand slowly deforming intraplate regions, where previous palaeoseismological and tectonic studies have focused merely on faults that ruptured within the instrumental or historical seismic records.

\section{REGIONAL SETTING}

The western and southern Mongolian landscape is dominated by the interplay of active tectonic terranes: the central Mongolian Hangay dome is a rigid block with margins along which far-field stresses related to the India-Eurasia collision (e.g., Tapponnier and Molnar, 1979) have caused transpressive strain localization in the form of the Altai and Gobi Altai mountain belts (i.e., Palaeozoic subduction and arc complex; Cunningham et al., 1997, Cunningham, 2001; Erdenetsogt et al., 2009). This has led to four major $\mathrm{Mw} \sim 8$ earthquakes in the 20th century (Figure 1; Tsetserleg: $\mathrm{Mw}=8.0,1905$, Bulnay: $\mathrm{Mw}=8.3,1905$, Fuyun: $\mathrm{Ms}=7.9,1931$ and Gobi Altai: $\mathrm{Mw}=8.1,1957$; Baljinnyam et al., 1993, Schlupp and Cisternas, 2007; references in Sodnomsambuu and Klyuchevskii, 2017). The area continues to deform under a NE-SW $\left(49^{\circ}\right)$ oriented maximum horizontal stress regime $\left(\mathrm{SH}_{\max }\right.$; Heidbach et al., 2016). The Hangay itself lacks instrumental seismicity and was long considered an aseismic, non-deforming block (Baljinnyam et al., 1993; Cunningham, 2001; Walker et al., 2008). However, Walker et al. (2007); Walker et al. (2008) observed normal faults that indicate late Quaternary activity. In relation to the regional strain field, these normal faults were interpreted to be part of a large E-W (NW-SE and N-S further east) strike-slip system that indicates active Holocene faulting in the Hangay. The Valley of Lakes separates the Altai mountain ranges from the Hangay. It forms a longitudinal basin that stretches from the northern border with Russia (where it is known as the Valley/Basin of Great Lakes) to the Gobi desert in southern Mongolia (i.e., the Valley of Gobi Lakes; VGL; Figure 1; Lehmkuhl et al., 2018a). It initially formed as a Carboniferous foreland basin that acted as a depocenter for sediments throughout ongoing subsidence in Permian and Jurassic times (Erdenetsogt et al., 2009). Late Cenozoic uplift and mountain building created the current transpressive setting (e.g., Cunningham, 2010). Active fault kinematics in both the South Hangay and the Gobi Altai reflect the regional E-W left-lateral strain field (Calais et al., 2003). Surface expressions do vary between transtensive (in the Hangay) and transpressive (in the Gobi Altai) systems, respectively (Ritz et al., 1995; Cunningham et al., 1997; Bayasgalan et al., 1999; Cunningham, 2001; Walker et al., 2007). The restraining bends in the Gobi Altai and the releasing bends within the Hangay may result from localized stresses or from the overprinting of structural weaknesses in the underlying crust, which are respectively NE-SW and NW-SE oriented in the South Hangay and Gobi Altai (Walker et al., 2007).

The TG is one of the largest ( $250 \mathrm{~km}$ long) rivers in the VGL and it flows into the endorheic Orog Nuur Basin. Large alluvial plains previously described as abandoned terraces of the TG (Walther, 1998; Lehmkuhl and Lang, 2001; Lehmkuhl et al., 2018) characterize the river valley north of the lake. Lehmkuhl et al. (2018) and Walther (1998) identified three terrace sets, however, no detailed mapping of the TG deposits has been performed. Optically stimulated luminescence (OSL) ages determined by Lehmkuhl et al. (2018); (T2: >162 $\pm 20 \mathrm{ka}, \mathrm{T} 1:>72 \pm 7 \mathrm{ka})$ and Nottebaum et al. (in review); (highest river terrace: $>133 \pm$ $10 \mathrm{ka})$ likely underestimate the age of TG deposits due to limitations of the dating method. The shape of Orog Nuur $(\mathrm{ON}$; nuur $=$ Mongolian for lake $)$ is dominated by the influx of alluvial fan sediments from the Gurvan Bogd range in the south and by active and inactive remnants of the TG fan from the north. Cenozoic aridification in southern Mongolia has been attributed to the uplift of the Hangay and Altai ranges (Caves et al., 2014) and has resulted in the preservation of Pleistocene to modern alluvial fan surfaces (e.g., Vassallo et al., 2007; Rizza et al., 2011; van der Wal et al., 2020). ${ }^{10} \mathrm{Be}$ cosmogenic nuclide exposure dating of these fan levels has shown that alluvial fans aggrade prior to, and incise during glacial-interglacial transitions, every \pm 100 kyr (Vassallo et al., 2007; Lehmkuhl et al., 2018). Erosion rates of alluvial fans along the Gurvan Bogd range were estimated to be between 6 and $9 \mathrm{~m} / \mathrm{Myr}$ (Rizza et al., 2011). The geomorphology of the Orog Nuur Basin reflects a Late Pleistocene to modern aridification with intermittent periods of higher lake levels, which are likely due to shifts in atmospheric moisture distribution (Nottebaum et al., in review). Remnants of multiple palaeoshorelines in the form of beach ridges or lake deposits indicate higher lake levels within and at the margins of the basin. Beach ridges occur up to $100 \mathrm{~m}$ above the current lake level and reflect a $100 \mathrm{kyr}$ lake history. Most prominently, a $56 \mathrm{~m}$ highstand during late MIS 5 and a $14-18 \mathrm{~m}$ highstand during Mid-Holocene times (Lehmkuhl and Lang 2001, Komatsu et al., 2001; Lehmkuhl et al., 2018a; Nottebaum et al., in review), indicate that the volume of $\mathrm{ON}$ was respectively 153 and 25 times larger than today (Nottebaum et al., in review). Such high lakestands, sustained for tens of thousands of years (Nottebaum et al., in review), may result from a combination of low evaporation, high precipitation and increased meltwater from the Hangay range (Komatsu et al., 2001). The Gurvan Bogd range constitutes the northernmost expression of the Gobi Altai transpressional system and marks the southern border of the Orog Nuur Basin. The range is marked by the 


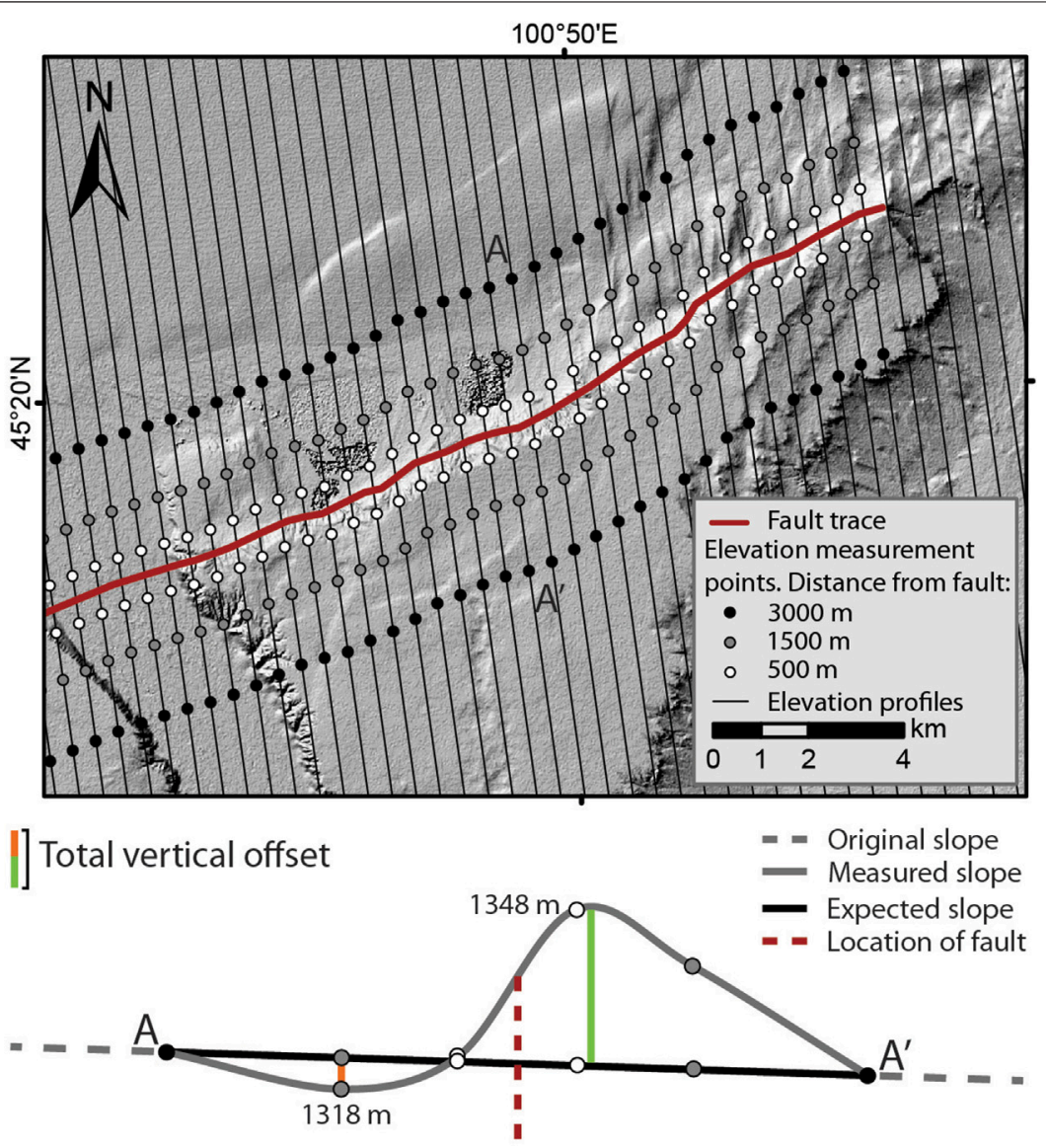

FIGURE 2 | Concept for vertical offset measurements showing elevation measurement locations at 500, 1,500 and 3,000 m on either side of a fault (top). Total (minimum) offsets are then estimated from the maximum difference between the measured elevations and the elevations expected from the estimated unperturbed alluvial fan surface (black line/gradient between A and A'; below).

tectonically active Bogd fault, which ruptured along a length of $>250 \mathrm{~km}$ during the $1957 \mathrm{Mw} \sim 8.1$ earthquake (e.g., Kurushin et al., 1997). Palaeoseismological studies along the Bogd fault determined Upper Pleistocene $0.5-1 \mathrm{~mm} / \mathrm{yr}$ horizontal slip rates (Rizza et al., 2011), <0.3 mm/yr vertical slip rates (Vassallo et al., 2005; Vassallo et al., 2007; Ritz et al., 2006; van der Wal et al., 2020), and showed that the 1957 earthquake was a characteristic event with 3-5 kyr recurrence intervals (e.g., Prentice et al., 2002; Rizza et al., 2011). At the TG fan apex, a low bedrock ridge with a linear mountain front cuts through the VGL and separates the outlet into ON from the abandoned alluvial fans of the TG further north (i.e., on either side of 'B' in Figure 1). Within the context of the surrounding deformation in the Hangay and along the Bogd fault (e.g., Vassallo et al., 2007; Walker et al., 2006; Walker et al., 2008; Cunningham, 2001; Cunningham, 2010), we explore the degree of tectonic activity along this bedrock ridge and along three sub-parallel $\sim \mathrm{E}-\mathrm{W}$ striking lineaments north of it, and we evaluate their effect on the TG drainage network and landscape evolution.

\section{METHODS}

We studied four fault scarps and their surrounding geomorphology to evaluate their tectonic history and earthquake potential. Field observations were complemented by analyses of $12 \mathrm{~m}$ resolution TanDEM-X data (German Aerospace Center, 2017).

\section{${ }^{10} \mathrm{Be}$ Cosmogenic Nuclide Analysis and Age Derivation}

Ten samples from fan surfaces and river channels were analyzed for ${ }^{10} \mathrm{Be}$ cosmogenic nuclide exposure dating. We sampled fluvially rounded, pure quartz pebbles from planar, unshielded fluvial surfaces that showed no evidence for recent surface modification. From the highest alluvial surface, i.e. the deposits west and east of the TG active channel, six samples, three each from two separate sites, were dated (black circles in Figure 2; labeled AF3 in tables); two samples were dated from the most recent deposit of a TG palaeochannel (gray circle in 
TABLE 1 | Input used in online calculator age estimates ${ }^{a}$.

\begin{tabular}{|c|c|c|c|c|c|c|c|}
\hline \multirow[t]{2}{*}{ Sample site } & Lat. & Long. & \multirow{2}{*}{$\frac{\text { Elev. }}{\text { m.a.s.l. }}$} & \multirow[t]{2}{*}{ Sample ID } & \multirow{2}{*}{$\frac{\text { Average sample thickness }}{\mathrm{cm}}$} & ${ }^{10} \mathrm{Be}$ conc. & ${ }^{10} \mathrm{Be}$ conc. $1 \mathrm{~s}$ \\
\hline & \multicolumn{2}{|c|}{ Dec. Deg. } & & & & \multicolumn{2}{|c|}{$\times 10^{6} \mathrm{at} / \mathrm{g}$} \\
\hline \multirow[t]{6}{*}{ AF3 } & 45.31366 & 100.82268 & 1,352 & ON_002i & 2.5 & 5.61 & 0.18 \\
\hline & 45.31366 & 100.82268 & 1,352 & ON_002ii & 2.5 & 2.98 & 0.10 \\
\hline & 45.31366 & 100.82268 & 1,352 & ON_002iii & 3 & 5.19 & 0.17 \\
\hline & 45.20874 & 100.61554 & 1,294 & ON_004Ci & 2.5 & 5.39 & 0.18 \\
\hline & 45.20874 & 100.61554 & 1,294 & ON_004Cii & 2 & 3.54 & 0.12 \\
\hline & 45.20874 & 100.61554 & 1,294 & ON_004Ciii & 3.5 & 4.84 & 0.16 \\
\hline \multirow[t]{2}{*}{ PC } & 45.20647 & 100.61143 & 1,282 & ON_004Ai & 2.5 & 1.49 & 0.05 \\
\hline & 45.20647 & 100.61143 & 1,282 & ON_004Aii & 4.0 & 1.68 & 0.06 \\
\hline \multirow[t]{3}{*}{ TG } & 45.19965 & 100.77969 & 1,265 & ON_005C-A & 3.0 & 0.95 & 0.03 \\
\hline & 45.19965 & 100.77969 & 1,265 & ON_005C-B ${ }^{b}$ & 3.25 & 1.04 & 0.03 \\
\hline & 45.19965 & 100.77969 & 1,265 & ON_005C-B2 ${ }^{\mathrm{b}}$ & 3.25 & 1.01 & 0.03 \\
\hline
\end{tabular}

a Other input into the online calculator that was consistent for all the samples included: applying the 'std' flag for the atmospheric pressure model; applying the '07KNSTD' flag for the AMS standards; a density of $2.6 \mathrm{~g} / \mathrm{cm} 3$; and a zero erosion rate. In all cases topographic shielding is negligible.

${ }^{b}$ Duplicate samples. See main text.

Figure 2; labeled PC in tables), and two samples from the active TG riverbed (white circle in Figure 2; labeled TG in tables) were analyzed to evaluate ${ }^{10} \mathrm{Be}$ pre-exposure (Table 1; Figure 2). Following crushing, two replicates of one of the active TG riverbed samples were prepared and measured separately. At the University of Cologne, samples were crushed and the $250-500 \mu \mathrm{m}$ size fractions were etched similarly to Kohl and Nishiizumi (1992). Following determination of low $\mathrm{Al}$ and $\mathrm{Ti}$ contents by in-house ICP-OES, the purified quartz samples and a corresponding laboratory blank were prepared as AMS (Accelerator Mass Spectrometry) targets following typical Cologne laboratory protocols and the single-step column approach detailed in Binnie et al. (2015). ${ }^{10} \mathrm{Be} /{ }^{9} \mathrm{Be}$ measurements were undertaken on CologneAMS (Dewald et al., 2013) and normalized to the revised standard values of Nishiizumi et al. (2007). Blank corrected sample ${ }^{10} \mathrm{Be}$ concentrations were determined following Binnie et al. (2019) and used as input into v. Three of the online calculator of Balco et al. (2008); (Table 1). We report ages using the production rate scaling scheme of Lifton et al. (2014).

\section{Morphotectonic Mapping}

We developed a geomorphological map by analyzing satellite images and TanDEM-X elevation data with $12 \mathrm{~m}$ resolution (German Aerospace Center, 2017). A discrepancy of TanDEM-X elevations was observed by Boulton and Stokes (2018) and was attributed to a lack of referencing to the EGM96 vertical reference frame. Because we base the analyses in this contribution on relative differences in TanDEM-X elevations, we disregard the discrepancy of absolute elevation values.

Geomorphological surfaces were distinguished based on optical differences such as roughness, texture, incision depth of streams and relative elevation. Faults were mapped where perturbations were observed within alluvial fan surfaces and where we observed disruptions of fluvial patterns. Relatively continuous lineaments were considered for the measurement of fault length; the length of F1 was measured along the E-W trending lineaments up until the westernmost termination of the fault against F2 (i.e., a NW-SE trending lineament). We determined fault kinematics based on geomorphological observations such as vertical displacements of fan surfaces, and in relation to the regional stress field. Where possible, we cross-checked and confirmed remote observations of fault kinematics in the field; however, the degradation of fault scarps and associated wide-spread deformation complicates local field observations.

\section{Offset Measurements}

We measured the lengths of four sub-parallel VGL fault scarps along continuous lineaments, and used the Wells and Coppersmith (1994) regression formulae to determine potential earthquake magnitudes and average offsets that can be accommodated by these faults. The kinematics of each fault were determined by morphotectonic observations.

We measured vertical displacements along the VGL fault scarps. Lateral displacements could not be observed with confidence due to weathered surfaces and deposition of aeolian sediments along the scarps. To estimate these vertical offsets, we evaluated elevations on either side of a fault from the TanDEM-X data. Perpendicular and from both sides to an average azimuth of each fault, we extrapolated elevations at $500, \quad 1,500$ and $3,000 \mathrm{~m}$ distance at $500 \mathrm{~m}$ along strike increments. To account for degradation of fault scarps, and taking into account their imprint on the landscape, we assume that deformation is spread over a wide area and that elevations at $500 \mathrm{~m}$ and $1,500 \mathrm{~m}$ from each mapped fault are a good representation of non-degraded offsets. The elevations at $3,000 \mathrm{~m}$ distance from the fault were used to determine a linear trend line that is assumed to represent an average, undisturbed alluvial fan slope. Subsequently, the expected elevations at the 500 and $1,500 \mathrm{~m}$ intervals were calculated and compared to the measured elevations at these intervals. We assume that the maximum difference (i.e., sum of negative and positive displacement corrected for fan slope) between expected and measured elevations roughly indicates the effect 


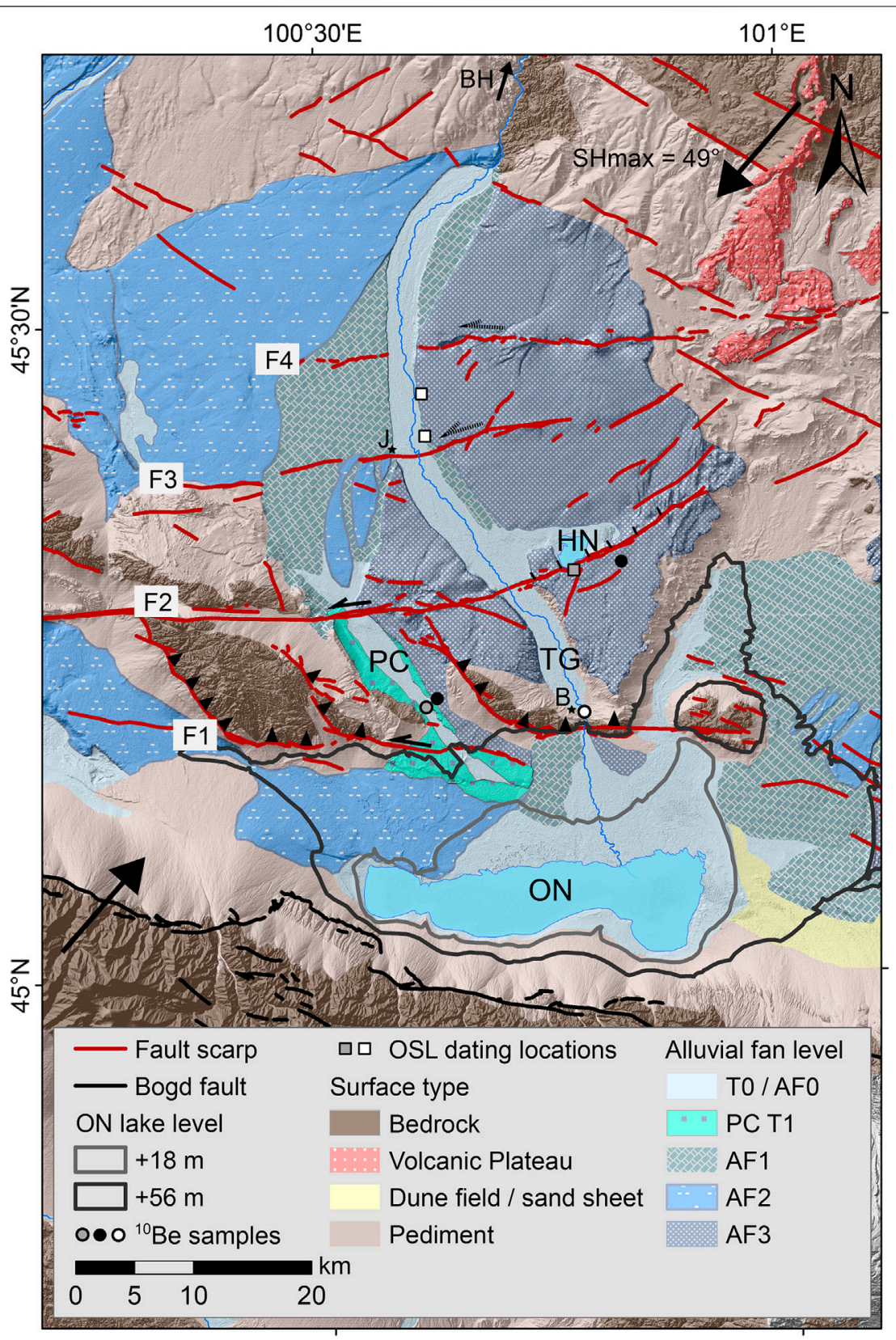

FIGURE 3 | Morphotectonic map of the VGL faults (F1, F2, F3, F4) and alluvial surfaces associated with the Tuyn Gol. Gray outlines indicate former lake level highstands of Orog Nuur. ${ }^{10} \mathrm{Be}$ sample locations are color coded based on the surface they represent: gray circle is the palaeochannel, black circles are the AF3 surface and the white circle is the active TG channel. White squares are the OSL dating locations of Lehmkuhl et al. (2018a) and gray squares are from Nottebaum et al. (in review). Abbreviations: PC, [alaeochannel; TG, Tuyn Gol; HN, Holboliin Nuur; ON, Orog Nuur; towns and settlements are abbreviated: BH, Bayankhongor; J, Jinst; B, Bogd.

of cumulative deformation on the fan profile (Figure 3). These measurements indicate a minimum estimate of cumulative vertical offset as post-seismic erosion and aggradation may have reduced the quantifiable offset. Finally, the tectonic offsets along each fault are estimated by averaging displacements at $500 \mathrm{~m}$ increments within each mapped geomorphological surface. Uncertainties are determined by the standard deviation of the along strike offset measurements. To simplify our interpretations, we assume that all deformation is vertical, coseismic, constant over time, and that it results from characteristic earthquake events. Additionally, we assume that fault displacements are equal along strike and that erosion has affected each mapped geomorphological surface homogeneously.

In combination with the exposure ages determined from cosmogenic nuclide dating we use our offset measurements to estimate minimum vertical slip rates. Assuming that the offset per event is always purely vertical, the average displacement per earthquake calculated with the regression formulae from Wells 


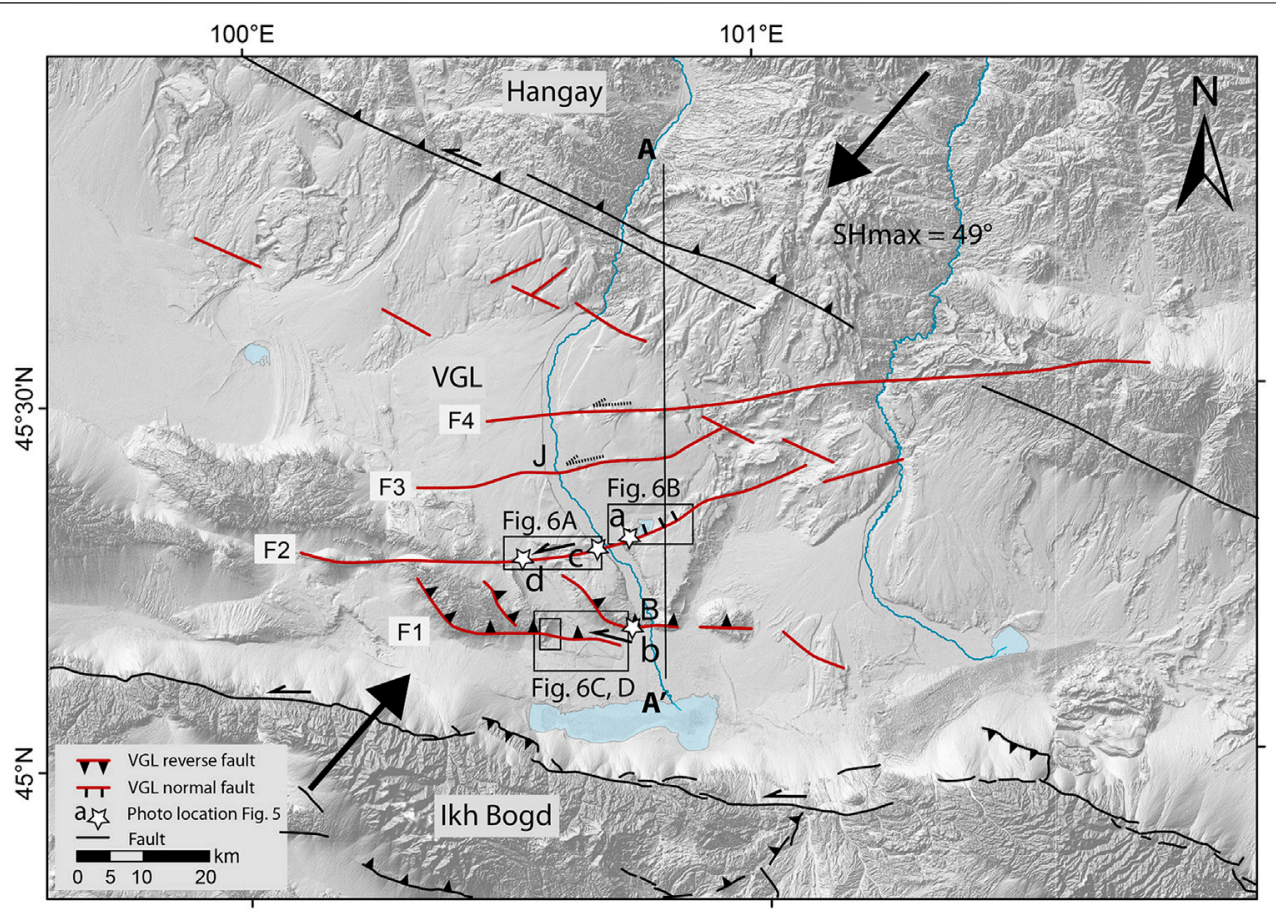

FIGURE 4 | Simplified tectonic map of the VGL faults with interpreted fault mechanisms within the framework of the Bayankhongor fault bounding the Hangay dome to its south, and the Bogd fault bounding the Ih Bogd mountain to the south (both in black). Cross section A-A' is shown in Figure 7 . SH $\mathrm{H}_{\text {max }}$ is shown by large arrows, as determined by Heidbach et al. (2016).

and Coppersmith (1994) allows us to estimate recurrence intervals along each of the faults. The assumption that all offset is vertical probably leads to an underestimation of recurrence intervals. Additional methods required to incorporate lateral offsets for more accurate slip rate and recurrence interval estimates are beyond the scope of this contribution. Uncertainties of slip rates and recurrence intervals were determined by error propagation of the uncertainties in the ages and offsets (Bevington and Robinson, 2003).

\section{RESULTS}

\section{Morphotectonic Observations}

Three main alluvial fan levels (AF1 to AF3) are observed along the TG between the Hangay dome and the Orog Nuur Basin (Figure 2). Numerous inset terraces have been observed along the river profile, most abundantly near the Hangay outlet (Walther, 1998; Lehmkuhl and Lang, 2001). Remnants of the highest fan level (AF3) are mainly preserved east of the TG with elevations of 20-30 $\mathrm{m}$ above the present river channel (Figure 2). The fan surface spans between the Hangay and the Bogd settlement and is covered by a homogeneous desert pavement directly underlain by aeolian silty sand (Nottebaum et al. in review). West of the active TG channel the geomorphology is more variable: just south of the Hangay, two alluvial fans (AF2 and AF1) are recognized that are both at lower elevations than AF3 east of the river. These deposits show a westward tilt. Further south, between the Jinst and Bogd settlements, a remnant of the highest fan level AF3 separates the TG channel from a $20 \mathrm{~km}$ long, $\quad 100-2,500 \mathrm{~m}$ (i.e., includes floodplains) wide palaeochannel that runs approximately parallel to TG (Figure 2). Here, AF3 is around $20 \mathrm{~m}$ higher than the incised palaeochannel, and two inset terrace levels at +5 and $+10 \mathrm{~m}$ are observed. At the outlet of the palaeochannel to the Orog Nuur Basin, we observe +52 and $+56 \mathrm{~m} \mathrm{ON}$ beach ridges to curve inward toward the palaeochannel. We interpret this intercalation of deposits to reflect coeval lacustrine and fluvial activity. No reliable offsets were observed in the active TG channel.

The TG alluvial fan deposits are cross-cut by four sub-parallel E-W striking lineaments which we further refer to as faults F1, F2, F3 and F4, from south to north, respectively (Figures 2, 4). Despite these lineaments being easily distinguishable from satellite imagery, the fault scarps are generally degraded and deformation is spread over a wide area (Figure 5A). The bedrock ridge bordering the northern margin of the Orog Nuur Basin (i.e., bounded by F1; west and east of the Bogd settlement) has a linear mountain front that implies active faulting, however no sharp fault scarps are observed. Satellite imagery shows that the bedrock ridge is cross-cut by multiple fault lines which have often been reused as fluvial pathways. At the mountain front, Quaternary deformation is less straight-forward. In some locations fluvial terraces and offset ridges may record active faulting, but the local deposition of aeolian sediments along the mountain front complicates the quantification of surface deformation. Lake deposits with 


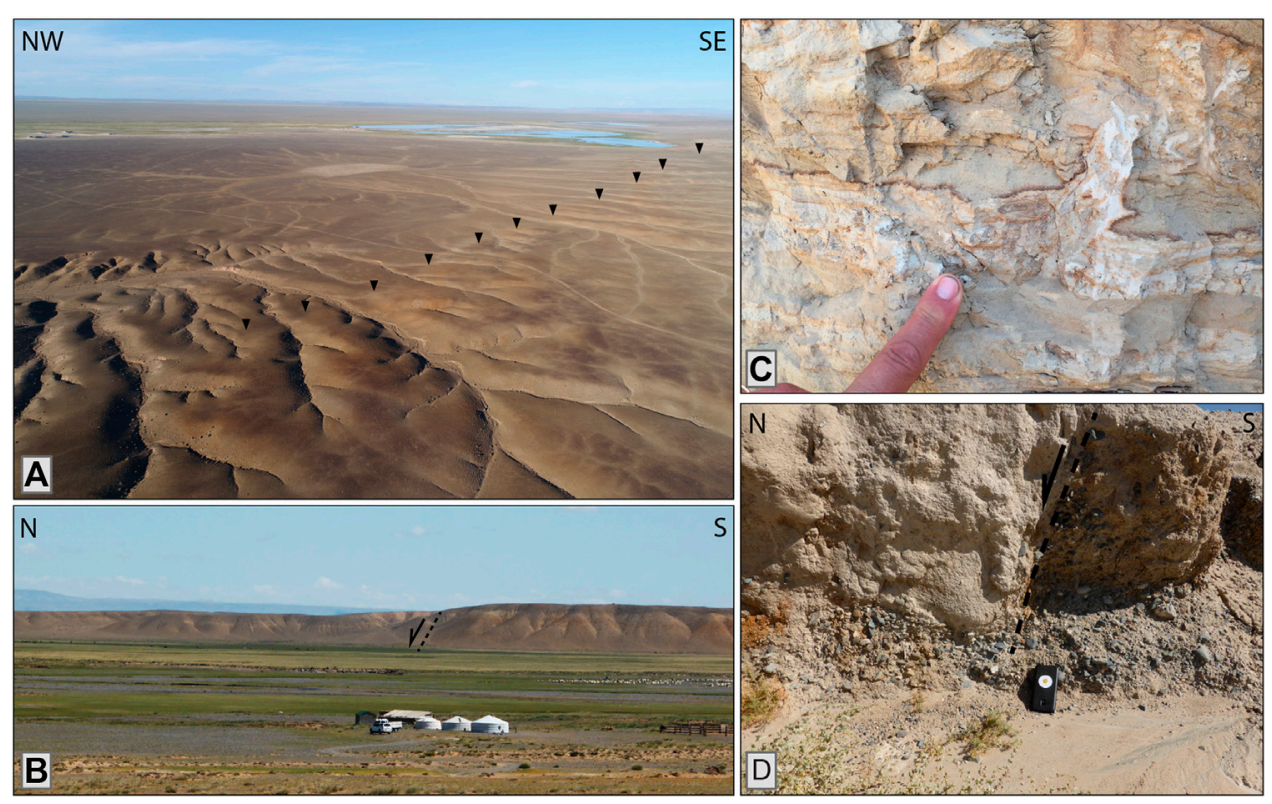

FIGURE 5 | Field photographs; locations are shown in Figure 4. (A) Overview of F2 toward Holboliin Nuur (looking NE) indicating the wide spread and degradation of the fault scarp. Black arrows indicate the fault line; (B) Liquefaction features in ON lake sediments along F1; (C) Side view of the F2 normal fault scarp displaying clear uplift of the southern block, looking (D,E) Minor offset observed within the palaeochannel, showing fine-grained sediments on the hanging wall that could indicate ponding; Samsung Galaxy J3 smartphone for scale $(14.2 \mathrm{~cm}$ by $7.1 \mathrm{~cm})$.

liquefaction features (Figure 5C) indicate fault activity between $77.5 \pm 5.3 \mathrm{ka}$ and $86.8 \pm 5.8 \mathrm{ka}$ (Nottebaum et al., in review), but this may also reflect seismic activity along another fault, such as the Bogd fault $\sim 50 \mathrm{~km}$ further south. The lacustrine sediments, as well as some bedrock outcrops, are covered by fluvial pebbles which we interpret to be remnants of the AF3 fan level. The AF3 surface does not occur south of F1, implying either that the fan level was not deposited here, or that young sediments cover the downthrown AF3 deposit. F1 is an E-W striking fault with NW-SE trending splays that cut through bedrock. Some left-lateral offsets are observed along the E-W strands (Figure 6C), however the topography, also in relation to the regional strain field, points toward dominantly oblique, reverse kinematics (Figure 4). In some locations, striations or slickensides are observed within the bedrock, but they are not pervasive enough to analyze in further detail and they may also reflect a prior episode of deformation. Both the TG palaeochannel and the active TG run parallel to the F1 NW-SE trending fault lines, implying that their incision postdates tectonic activity. The fan apex of the modern, active TG fan coincides with a narrow $\sim 20 \mathrm{~m}$ wide gorge at the Bogd settlement, where TG flows perpendicularly to F1. The decrease in floodplain width from $\sim 3,500 \mathrm{~m}$ further upstream to $20 \mathrm{~m}$ indicates that the $\mathrm{F} 1$ fault still actively affects the modern day TG channel morphology. At the outlet of the palaeochannel, ca. $10 \mathrm{~km}$ further west, the F1 fault scarp cuts through the $+5 \mathrm{~m}$ inset terrace and across a bedrock ridge that is clearly offset laterally. Nevertheless, no quantifiable offsets were observed in the field (Figures 6C,D).

F2 has a variable orientation along strike, relative to the NESW direction of maximum principal stress, which has implications for the kinematics we observe along the fault. East of TG, and just south of Holboliin Nuur (Figure 6B), the fault has a NE-SW orientation and the AF3 fan here is upthrown in the south (Figure 5B); we interpret this to be a north-dipping normal fault. The homogeneity and desert varnish of the AF3 surface is easily recognized in the field, and a remnant of AF3 is clearly vertically offset by $>15 \mathrm{~m}$ between the active TG channel and Holboliin Nuur (Figure 6A). West of TG, the fault azimuth rotates to $\mathrm{E}-\mathrm{W}$ and shows much less vertical displacement but rather a series of sigmoidal ridges (Figure 6A); we interpret the fault to be strike-slip here. Within the palaeochannel, two parallel fault strands are observed, which downthrow the southern block by a total of $\sim 8-10 \mathrm{~m}$. A small, eroded outcrop within the palaeochannel shows a steep normal fault with finer sediments on the hanging wall, implying relatively recent (temporary) ponding as a result of $\sim 0.5 \mathrm{~m}$ vertical offset (Figure 5D). Further west, there seems to be a further rotation of the fault, with increasing uplift of the northern block, indicating a clear reverse component here. The curved nature and decreasing continuity of the surface expression of F2 toward the west may either indicate a change in kinematics or, more likely, point toward fault segmentation. The continuity of the scarp between the AF3 surface east of Holboliin Nuur and the area west of the palaeochannel implies that these segments did rupture together. We therefore regard F2 as a single fault. Tilting of Holboliin Nuur beach ridges (Figure 5B) has not been observed, which would have indicated simultaneous or postdepositional fault activity along F2. Nevertheless, the highest beach ridge remnants are observed in closest vicinity to the fault (Figure 5B) and detailed, higher resolution topographic 


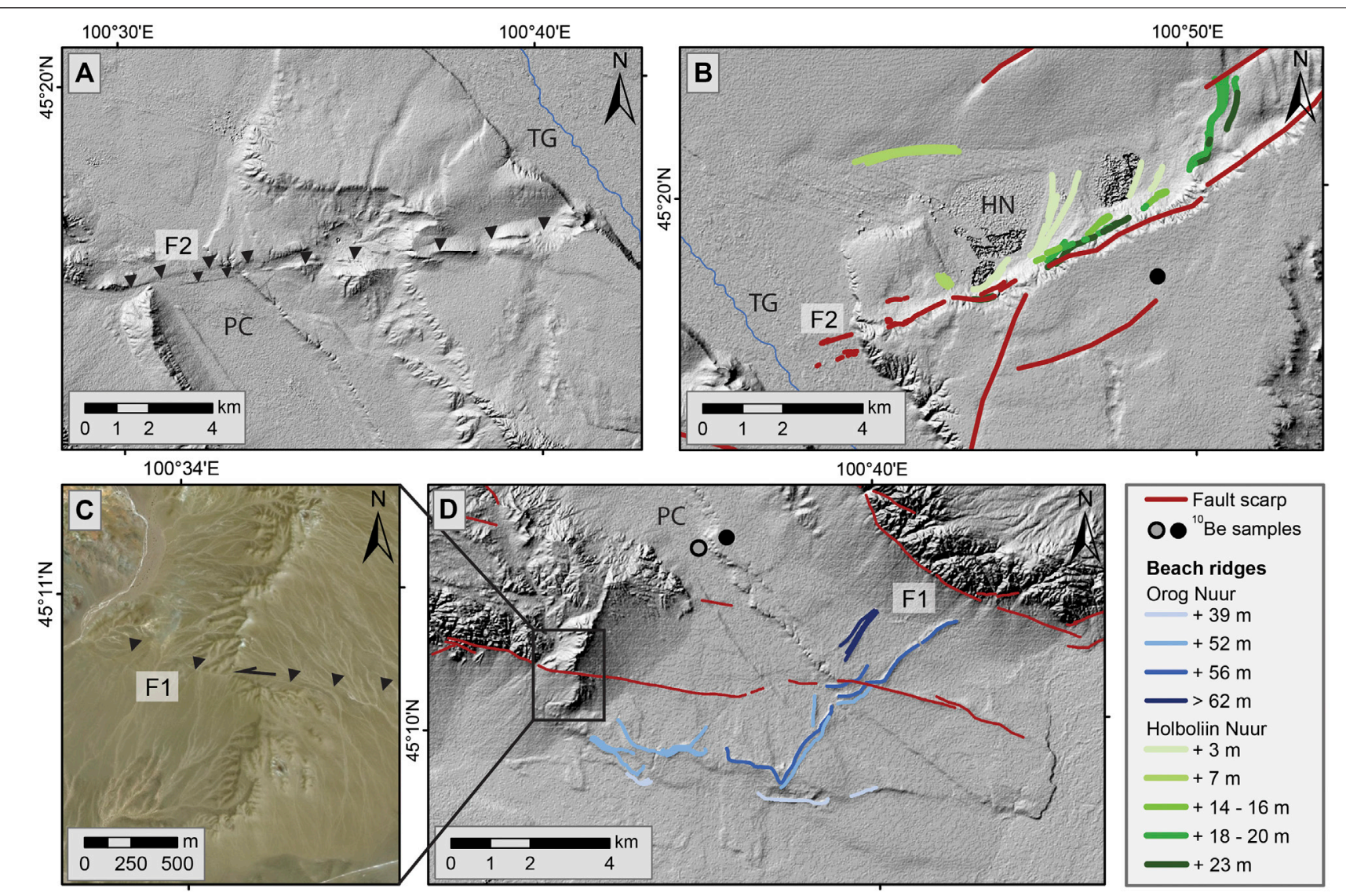

FIGURE 6 | Detailed TanDEM-X imagery showing surface expressions of faults and beach ridges. (A) Sigmoidal ridges interpreted as strike slip offsets along F2 and two well defined fault scarps across the palaeochannel; black arrows indicate fault F2; (B) Beach ridges associated with Holbolin Nuur, and normal fault offset along F2; (C) Left-lateral strike-slip along F1 just west of the palaeochannel outlet into the Orog Nuur Basin; (D) Palaeochannel outlet interference with multiple beach ridges associated with Orog Nuur lake levels $>56 \mathrm{~m}$ higher than the present lake level (Nottebaum et al., in review). ${ }^{10} \mathrm{Be}$ sample locations are color coded based on the surface they represent: gray circle is the paleochannel, and black circles are the AF3 surface. Abbreviations: HN, Holboliin Nuur; PC, palaeochannel; TG, Tuyn Gol.

analyses and dating would be necessary to confirm whether these beach ridges reflect a climatic signal (as seen at ON), or whether they reflect postdepositional tectonic uplift.

The kinematics of F3 and F4 remain ambiguous because minor drainages have localized along the scarps here, creating local erosion and a more variable topography and thus, less clear fault offsets. The preservation of AF2 alluvial fan remnants along F3 just west of the Jinst settlement (Figure 2), and the westward deflection and incision of a southward draining channel at F4, do imply uplift of the southern block. However, the lack of clear vertical displacements in combination with the orientation of these scarps relative to the regional stress field implies that they may be taking up a component of left-lateral slip. Overall, the four fault scarps are best defined within the AF3 fan level east of TG. Although F1 and F2 continue further west and also offset the palaeochannel (Figure 6A), the surface expressions of F3 and F4 are clearest east of TG and fade out toward the west.

\section{Cosmogenic Nuclide Ages}

Blank corrected sample ${ }^{10} \mathrm{Be}$ concentrations vary between 5.61 $\times 10^{6}$ and $9.50 \times 10^{5} \mathrm{at} / \mathrm{g}$ (Table 1). The in-batch reagent
TABLE $2 \mid{ }^{10} \mathrm{Be}$ exposure ages with associated morphological surfaces: PC, Palaeochannel (lowest terrace/most recent deposit); TG, Tuyn Gol active channel. Ages are derived from v.3 of the online calculator of Balco et al. (2008) and are based on the LSD scaling scheme of Lifton et al. (2014). Uncertainties quoted below are 1 standard deviation "external" values that include production rate as well as analytical uncertainties.

\begin{tabular}{llc}
\hline Surface & Sample ID & Age (ka) \\
\hline AF3 & ON_002i & $483 \pm 37$ \\
& ON_002ii & $242 \pm 17$ \\
& ON_002iii & $444 \pm 34$ \\
& ON_004Ci & $488 \pm 38$ \\
& ON_004Cii & $304 \pm 22$ \\
& ON_004Ciii & $436 \pm 33$ \\
PC & ON_004Ai & $126 \pm 9$ \\
& ON_004Aii & $144 \pm 10$ \\
TG & ON_005C-A & $83 \pm 6$ \\
& ON_005C-B & $90 \pm 6$ \\
& ON_005C-B2 & $88 \pm 6$
\end{tabular}

(laboratory) blank measurement amounted to less than $0.4 \%$ of the ${ }^{10} \mathrm{Be}$ measured in the samples. The six exposure ages of fan level AF3 vary between $242 \pm 17 \mathrm{ka}$ and $488 \pm 38 \mathrm{ka}$ (Table 2; 
TABLE 3|Earthquake potential estimates based on Wells and Coppersmith (1994) and fault length measurements across the $400 \pm 102$ ka AF3 surface east of the Tuyn Gol active channel. In combination with results from Table 2, recurrence intervals and slip rates were determined.

\begin{tabular}{|c|c|c|c|c|c|c|}
\hline Fault & $\begin{array}{l}\text { Fault length } \\
\text { (km) }\end{array}$ & Moment magnitude & $\begin{array}{l}\text { Average offset } \\
\text { per event } \\
\text { (m) }\end{array}$ & $\begin{array}{l}\text { Measured offset } \\
\qquad(\mathrm{m})\end{array}$ & $\begin{array}{l}\text { Recurrence interval } \\
\text { (kyr) }\end{array}$ & $\begin{array}{l}\text { Slip rates } \\
\text { (mm/yr) }\end{array}$ \\
\hline $\mathrm{F} 1$ & 62.1 & 7.19 & 0.68 & $52.2 \pm 22.4$ & $5.24 \pm 2.61$ & $0.13 \pm 0.07$ \\
\hline $\mathrm{F} 2$ & 67.2 & 7.27 & 1.35 & $31.70 \pm 7.97$ & $17.1 \pm 6.1$ & $0.08 \pm 0.03$ \\
\hline F3 & 41.1 & 6.95 & 0.99 & $4.87 \pm 2.45$ & $81.57 \pm 46.05$ & $0.012 \pm 0.007$ \\
\hline $\mathrm{F} 4$ & 85.1 & 7.32 & 1.78 & $20.4 \pm 10.5$ & $34.9 \pm 20.1$ & $0.05 \pm 0.02$ \\
\hline
\end{tabular}

black circles in Figure 2). The samples from the palaeochannel ( $\mathrm{PC}$ in figures, marked by gray circle in Figure 2) give two ages of $126 \pm 9 \mathrm{ka}$ and $144 \pm 10 \mathrm{ka}$. The two samples from the active TG river show equivalent ages of $83 \pm 6 \mathrm{ka}$ and $90 \pm 6 \mathrm{ka}$ (white circle in Figure 2). Concentrations from the replicate samples (ON_005C-B and ON_005C-B2) collected at this site agree within uncertainties and we report the equivalent age from ON_005C-B (Table 1). In general, the exposure ages of the terrace sequence within the palaeochannel, as well as the ages from the modern channel, are in stratigraphic order, with the youngest originating from the lowest surface. Scatter in exposure ages from clasts taken at the surface of depositional fluvial features is common (Repka et al., 1997), and two of the six AF3 ages are notably younger. Underestimates of cosmogenic nuclide exposure ages from depositional landforms can derive from post-depositional erosion of the sample, or its burial and exhumation (Binnie et al., 2020). Alternatively, the pre-exposure history of clasts prior to their deposition on sampled surfaces can result in age overestimates (Anderson et al., 1996), and the results from the active channel indicate a significant portion of the ${ }^{10} \mathrm{Be}$ concentration measured in the AF3 and palaeochannel samples could have been inherited during pre-exposure. In addition, depositional fluvial features can form over a period of time that is significant relative to the age of the surface (D'Arcy et al., 2019). More resolute definitions of nuclide inheritance and surface modifications at these sites would require measurements at several meters depth, but in the absence of such profile measurements we consider an arithmetic mean and standard deviation of $400 \pm 102 \mathrm{ka}$ (1 s.d.) to be the most appropriate first order estimate for the age of the AF3 surface. We note this range would account for inheritance in the oldest samples if it is similar to what we measure in the modern channel and we assume that younger ages derive from surface modification, e.g., burial. Younger ages due to clast erosion seem unlikely given the preserved fluvially rounded form of the samples. The two samples from the palaeochannel give a relatively good agreement but had more measurements been possible increased scatter might be expected. We suggest a mean of the two ages is the most appropriate for the timing of abandonment of the palaeochannel and use the same relative uncertainty (coefficient of variation) as is found for AF3, giving $135 \pm$ 34 ka (1 s.d.).

\section{Tectonic Activity}

The lengths of faults F1-F4 range between 40 and $90 \mathrm{~km}$ (Table 3). Despite the variability in fault kinematics along strike (especially at F2), scarp continuity indicates that potentially segmented faults are likely rupturing simultaneously or in clusters. Considering the kinematics we determined from morphotectonic analysis and the Wells and Coppersmith (1994) fault rupture length-magnitude regressions, the VGL fault lengths allow us to estimate their potential earthquake moment magnitudes between 6.95 and 7.32. Average displacements along the VGL faults range between 0.66 and $1.78 \mathrm{~m}$ per earthquake (Table 3). Vertical displacements of the AF3 terrace, associated with each fault scarp, amount to $52.2 \pm 22.4 \mathrm{~m}$ (F1), $31.70 \pm 7.97 \mathrm{~m}$ (F2), $4.87 \pm 2.45 \mathrm{~m}(\mathrm{~F} 3)$ and $20.4 \pm 10.5 \mathrm{~m}$ (F4; see Table 3 ). Likely, measurements across F1 overestimate the true slip: no AF3 terrace remnants are observed on the southern side of the fault. Nevertheless, we use the $52.2 \pm 22.4 \mathrm{~m}$ estimate as an indication of the total vertical offset along fault F1. Dividing the offset values per fault by the $400 \pm 102 \mathrm{ka}$ age for the AF3 surface leads to minimum vertical slip rate estimates of $0.13 \pm 0.07 \mathrm{~mm} /$ $\mathrm{yr}, 0.08 \pm 0.03 \mathrm{~mm} / \mathrm{yr}, 0.012 \pm 0.007 \mathrm{~mm} / \mathrm{yr}$ and $0.05 \pm 0.02 \mathrm{~mm} /$ $\mathrm{yr}$, respectively. This means that these faults accommodate a total of $0.27 \pm 0.08 \mathrm{~mm} / \mathrm{yr}$ vertical slip, which is around the same order as the vertical slip taken up by the Bogd fault further south. Recurrence intervals estimated from the average slip per earthquake determined by the Wells and Coppersmith (1994) regressions, our offset measurements and the estimated $400 \pm$ $102 \mathrm{ka}$ age of $\mathrm{AF} 3$, are $5.24 \pm 2.61 \mathrm{kyr}(\mathrm{F} 1), 17.1 \pm 6.1 \mathrm{kyr}$ (F2), $81.5 \pm 46.0 \mathrm{kyr}(\mathrm{F} 3)$ and $34.9 \pm 20.1 \mathrm{kyr}(\mathrm{F} 4)$.

Reliable offset measurements of other surfaces are challenging, because either the surfaces are not large enough for elevation measurements that span $6,000 \mathrm{~m}$, or because, in the cases of F3 and $\mathrm{F} 4$, the faults only show minor surface displacements outside of AF3. Along F2, we measured offsets within the strike-slip segment in AF3 west of TG, and within the palaeochannel. The AF3 terrace west of the river has vertical offsets of $20.4 \pm 7.8 \mathrm{~m}$, a slip rate of $0.05 \pm 0.02 \mathrm{~mm} / \mathrm{yr}$ and a recurrence interval of $28.7 \pm$ $13.2 \mathrm{kyr}$. Within the palaeochannel we observed $10.2 \pm 6.3 \mathrm{~m}$ vertical offset. Taking strike-slip kinematics and an average age of $135 \pm 34 \mathrm{ka}$ into account, we estimate a slip rate of $0.08 \pm$ $0.02 \mathrm{~mm} / \mathrm{yr}$ and a recurrence interval of $19.4 \pm 4.9 \mathrm{kyr}$. Around $90 \mathrm{kyr}$ of pre-exposure is suggested by the ${ }^{10} \mathrm{Be}$ concentrations measured in the active channel (TG) samples, and if this is representative of the pre-exposure experienced by 
the TG samples then the palaeochannel is notably younger, and the slip rates faster than estimated above. Despite this, a comparison to estimates from the AF3 fan indicates that slip rates are relatively constant on a Middle Pleistocene to modern time scale.

\section{DISCUSSION}

\section{Tectonic Setting}

We studied faults in the VGL that cut across sediments deposited by the TG and evaluated their kinematics, earthquake potential and slip rates. To simplify interpretations of the fault system, we assumed that all offsets along the VGL faults are vertical. However, both remote and field observations showed that the tectonic structure of the VGL is complex and rather characterized by oblique slip. Although a lack of (temporally constrained) surface markers limits a reliable quantification of horizontal offsets, their importance may not be ignored in the interpretation of the regional tectonic setting. Most vertical offset is observed along the reverse F1 fault, which has a minor component of left-lateral slip. We interpret this fault to be the major transpressive fault within the VGL system. Faults F1 and F2 fit well into the regional stress regime, but the kinematics along F3 and F4 remain ambiguous. Possibly, their vertical offsets have been masked by erosion of the AF3 surface. Alternatively, these faults accommodate strike-slip movement, which could have been masked by the reworking of sediments within the active Tuyn Gol channel. The large vertical offset measured along F4 is likely the effect of the localization and incision of a faultparallel stream rather than tectonic offset. The localization and rerouting of this stream from approximately N-S to E-W however implies relative uplift of the southern block, indicating either a southward dipping fault with a reverse component, or a northward dipping fault with a normal component. Potential earthquake magnitudes along each of the four faults are approximately $\mathrm{M} \sim 7$. However, F1 and F2 are in line with faults further west which could potentially be connected at depth, implying larger potential magnitudes and shorter recurrence intervals. Despite the lateral variation in kinematics as a result of differences in fault strike, the continuity of lineaments implies that potentially segmented faults are rupturing simultaneously or in clusters. The cumulative $0.27 \pm 0.08 \mathrm{~mm} / \mathrm{yr}$ vertical slip rate of $\mathrm{F} 1-\mathrm{F} 4$ is similar to the $<0.3 \mathrm{~mm} / \mathrm{yr}$ vertical slip rates estimated along individual fault strands of the Bogd fault, that lies $\sim 50 \mathrm{~km}$ further south (Vassallo et al., 2005; Ritz et al., 2006; Vassallo et al., 2007; van der Wal et al., 2020). The similarity of cumulative vertical slip rates of these two fault systems implies that the faults studied here are indeed important within the context of strain accommodation and partitioning in southern Mongolia. Nevertheless, analysis of lateral offsets is necessary to quantify this further. In comparison to recurrence intervals of major earthquakes along the Bogd fault (3-5 kyr; e.g., Rizza et al., 2011), the VGL faults are deforming much slower, at $5.24 \pm 2.61 \mathrm{kyr}$ to $81.57 \pm 46.05 \mathrm{kyr}$ intervals. The diffuse morphology of VGL fault scarps probably results from these long intervals of seismic quiescence. Likely, the difference in recurrence intervals between the Bogd fault and the VGL faults is the result of the shorter measured fault lengths in the VGL. The faults may in reality be longer; therefore, additional topographic- and depth analyses, both remote and in the field, are necessary to determine the potential linkage of the VGL faults to scarps further west. Depth data are also necessary to determine how the VGL faults fit within the framework of Gobi Altai and Hangay active faulting. The kinematics and the stress regime we observe in the VGL imply a dominantly oblique, strike-slip setting, similar to what is observed in the Gobi Altai and the Hangay (e.g., Ritz et al., 1995; Vassallo et al., 2005; Ritz et al., 2006; Walker et al., 2006; Vassallo et al., 2007; Walker et al., 2007; Walker et al., 2008; Cunningham, 2010; Rizza et al., 2011; Kurtz et al., 2018), although the geometry may also reflect a foreland basin setting (Erdenetsogt et al., 2009). We propose two tectonic models for the area (Figure 7). The first model (Figure 7A) assumes reactivation along foreland basin faults within the VGL, with F1 being the toe thrust and F2-F4 being minor faults within the hanging wall. This would be in line with geological maps published by Mosionzd et al. (1988) in which Neogene and Palaeogene sediments north of faults F1 and F2 tilt toward $\mathrm{N}$ with a northward younging direction, implying a piggy-back-like stacking of sediments (Figures 7A,C). In this model, F2 was then likely also a southward verging thrust fault that has now been reactivated as a normal fault. Alternatively, Cenozoic reactivation of foreland basin faults or other crustal weaknesses created a dominantly transpressive geometry (Figure 7B). This would fit well with the depth of the minor earthquakes in the instrumental record (Figure 1), and it would match the active structures observed in the Gobi Altai and the Hangay.

Resistivity models and magnetotelluric data from Käufl et al. (2020) and Comeau et al. (2020) highlight that surface resistivity in the VGL is low. Although the authors attribute this to the conductivity of porous sediments and evaporites deposited here, a closer inspection shows that the anomalies seen in Käufl et al. (2020) align well with the faults described in this contribution. A contrasting high surface resistivity in the Hangay suggests that the VGL faults are more similar to the low resistivity faults of the Gobi Altai, yet the VGL is underlain by a resistive rather than a conductive lower crust (Käufl et al., 2020). The resistivity model of Comeau et al., 2020; (Figure 8) shows a decrease in resistivity directly below the VGL faults, implying that these faults are indeed upper crustal features. However, the major Gobi Altai and Hangay fault systems align with conductive zones that reach into the lower crust and maybe even the upper mantle (Cunningham, 2010 and references therein). These major fault systems are separated from the VGL faults by high resistivity zones, the base of which coincides with the depth of the $\mathrm{M} \sim 4$ instrumental earthquakes measured here (Figure 1). We regard it unlikely that the VGL faults are shallow upper crustal splays of either of the surrounding fault systems, or distal expansions of transpressional mountain belts, such as is observed in the Altai (Howard et al., 2006). Therefore, if the fault systems do connect at depth, they must do so below the resistive 


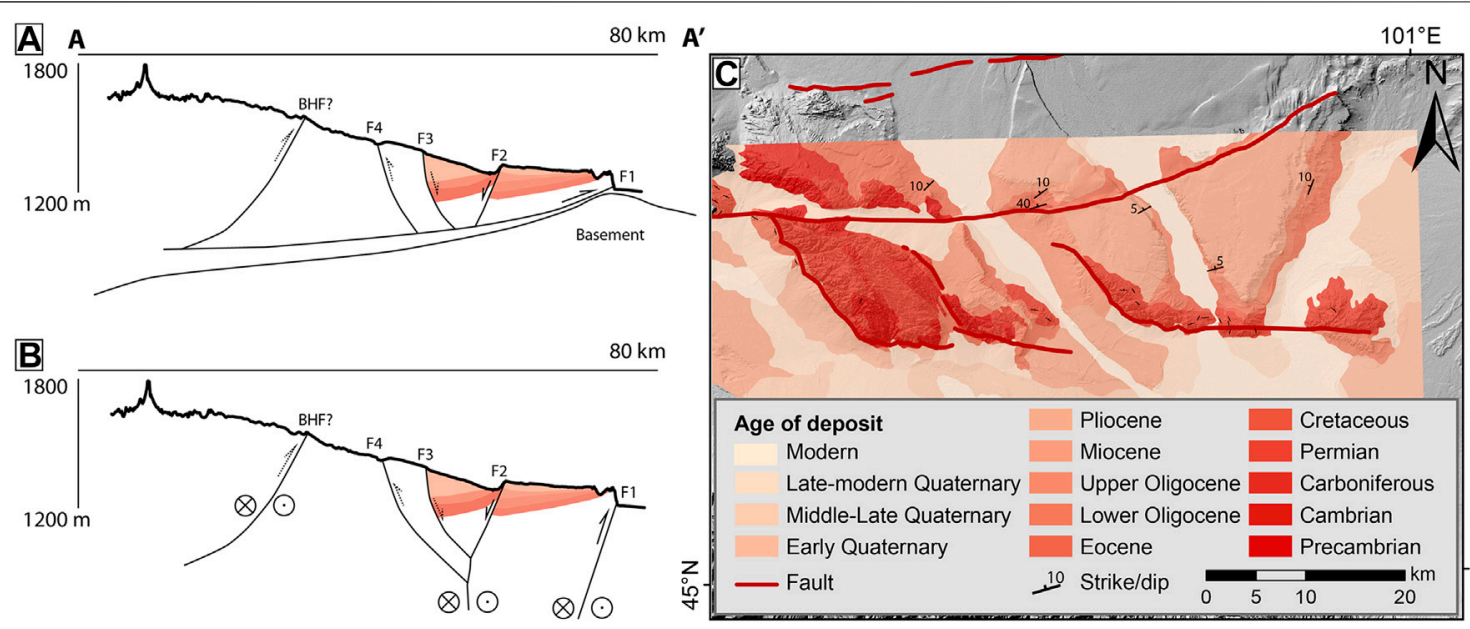

FIGURE 7 | Two conceptual models for VGL fault geometry at depth (up to an estimated 5-10 km depth; see Figure 8) along the N-S profile indicated in Figure 4. Figure 7A implies a foreland basin system with thin-skinned southward verging faults; (B) suggests deeply rooted strike-slip faults that display vertical displacements at the surface. The interpreted continuation of strata at depth is based on strike-dip measurements by Mosionzd et al. (1988); (C) Simplified geological map by Mosionzd et al. (1988) showing ages of the deposits and their orientations. Cretacous-modern deposits are mostly sediments; Palaeozoic strata consist of volcanic, intrusive and metamorphic rocks.

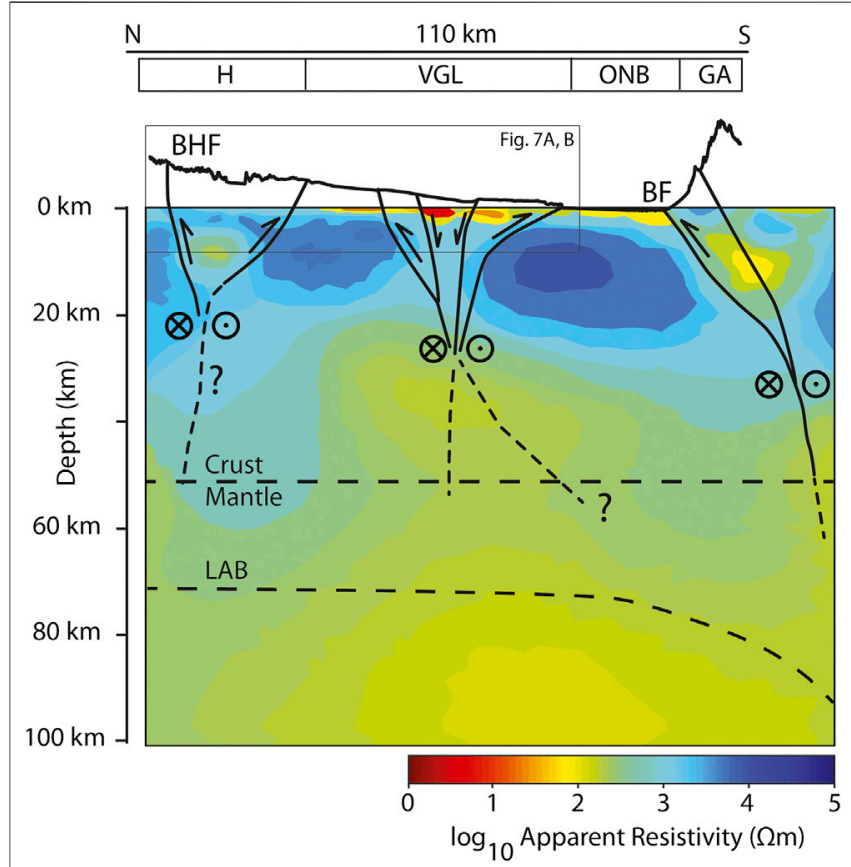

FIGURE 8 | Conceptual cross section across the Hangay and Gobi Altai areas showing the suggested VGL fault geometry at depth in correlation with the resistivity model by Comeau et al. (2020). H, Hangay; VGL, Valley of Gobi Lakes; ONB, Orog Nuur Basin; GA, Gobi Altai; BHF, Bayankhongor fault; BF, Bogd fault; LAB, lithosphere asthenosphere boundary (Comeau et al., 2020).

upper crust. The average orientation of the surrounding fault systems implies that further west, the Bogd fault may link up to the westward continuation of faults F1 and F2; further east, a SE- ward continuation of the Bayankhongor fault (BHF in Figure 4) forms a high angle with the VGL faults. We interpret from these observations, that the VGL faults are a diffuse northward continuation of the Gobi Altai deformation front and display stress transfer from the Bogd fault to the foreland. Similarly to surrounding fault systems, the localization of the VGL faults is related to underlying crustal fabrics that were overprinted or reactivated by Cenozoic transpression (e.g., Cunningham, 2005; Walker et al., 2008; Walker et al., 2015). Alternatively, the VGL faults highlight strain accommodation at the transition between the localized deformation in the basin-and-range Gobi Altai, and the passive indentor that is the Hangay. This seems likely considering both the active deformation and local expansion of the Gurvan Bogd mountain range (e.g., Bayasgalan et al., 1999; Vassallo et al., 2007; van der Wal et al., 2020), and the orientation of the VGL faults. Onset of deformation along the VGL faults would then have coincided with or followed shortly after the start of uplift along the Gurvan Bogd range at $5 \pm 3 \mathrm{Ma}$ (Vassallo et al., 2007a). This is also shown by the faulted Neogene sediments mapped by Mosionzd et al. (1988); (Figure 7C). The diffusivity, slow rates and long recurrence intervals observed along the VGL faults are in line with observations from Walker et al. (2007) and Walker et al. (2008) of faults in the Hangay, and they indicate intraplate strain partitioning across a larger area than previously envisaged (see also Meltzer et al., 2019). The N-S decreasing velocity gradient observed by Calais et al. (2003) indicates a clear decrease in the fault-parallel east velocity component north of the Gobi Altai between longitudes $96^{\circ}$ and $104^{\circ} \mathrm{E}$. Perhaps, this is the reason for the ambiguity of both the lateral slip along the VGL faults and their role in the regional structure. Because fault-perpendicular velocities are less well constrained (Calais et al., 2003) and we could only measure vertical offsets, it is challenging to infer a percentage of regional slip that is being accommodated by the VGL faults. 

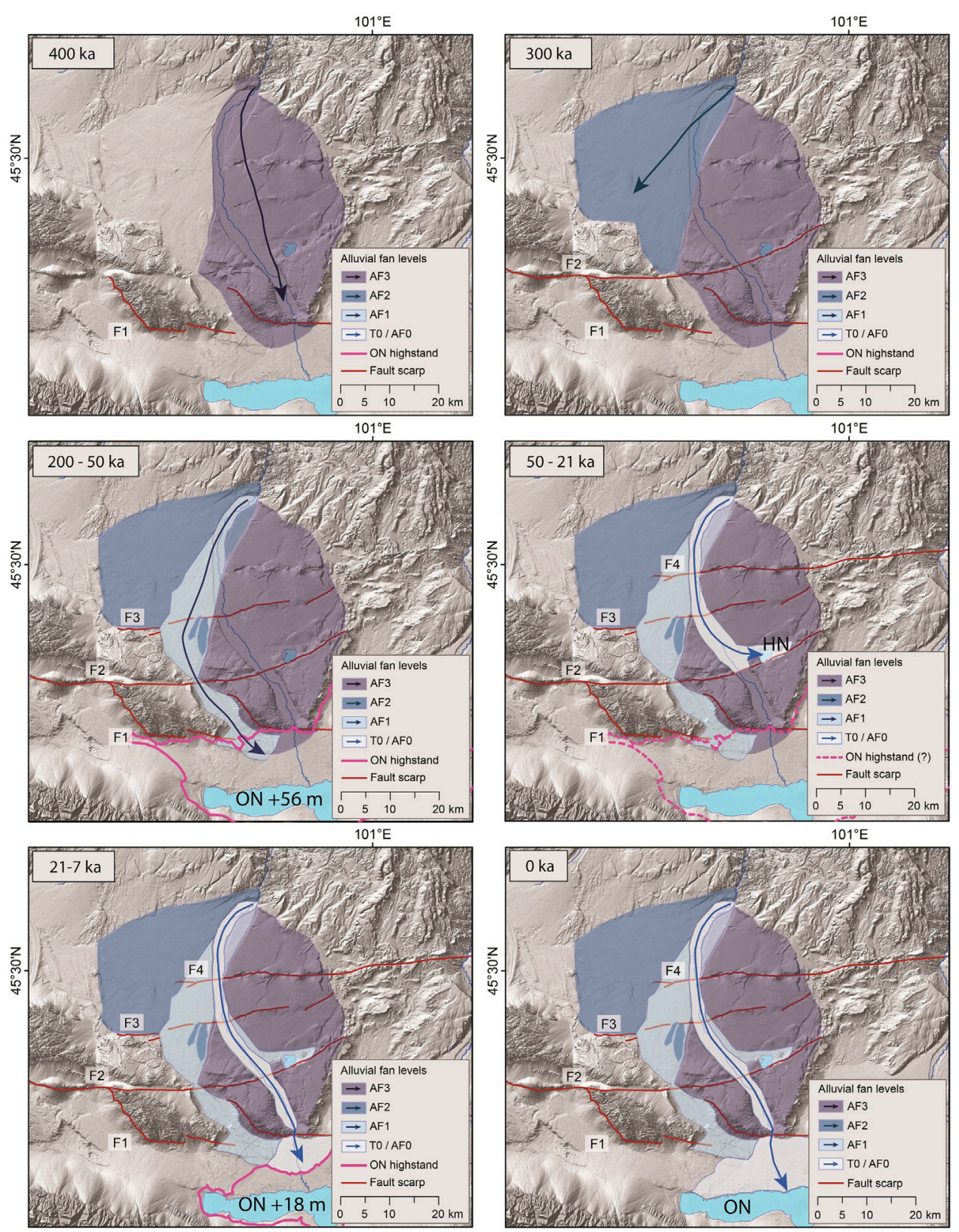

FIGURE 9 | Proposed landscape evolution of the VGL, since 400 ka on the top left, to the current situation in the bottom right. Lighter colors are associated with younger deposits, arrows indicate possible flow directions. The interpreted ages are based on ${ }^{10} \mathrm{Be}$ cosmogenic nuclide dating in this contribution, OSL ages associated with lake level highstands (Nottebaum et al., in review) and the assumption that alluvial fans aggrade during glacial times and incise at the transition to, or during interglacial times (Vassallo et al., 2007). HN, Holboliin Nuur; ON, Orog Nuur.

Overall, the VGL faults reflect the wide spread of deformation in southern Mongolia and additional studies of such faults will increase our understanding of the development of intraplate tectonic settings, specifically in relation to the relatively new concept of transpressional orogens (Cunningham, 2005). Active deformation in Central Asia is known to occur by thrusting, oblique- and strike-slip faulting (Cunningham, 2005) and by the expansion of orogens by widening positive flower structures (Cunningham et al., 1997), however research of relatively minor faults such as those in the VGL is limited. In comparison to pure strike-slip segments of the same fault, transpressive deformation may be more complex and widespread and further research is necessary to understand the evolution of such structures. Especially in the vicinity of densely populated areas, the consequences of earthquakes along such faults may be disastrous and regional tectonic studies are necessary to provide reliable seismic hazard assessments. Tectonic geomorphology studies, complimented 
by depth data, elsewhere in the Valley of Lakes and in the foreland of neighboring transpressional mountain belts, will determine if the VGL faults reflect a systematic evolution of known fault systems (e.g., the widening of flower structures), or whether they are a (common) strain accommodation feature at the transition from rheologically weak crust to rigid basement blocks (Cunningham 2005).

\section{Landscape Evolution}

To determine the effect of tectonic activity along the VGL faults on local landscape evolution, we evaluated the fluvial geomorphology of the TG as well as its palaeochannel, and beach ridges related to lake level highstands of Orog Nuur and Holboliin Nuur. To evaluate changes in the drainage network over time, we combine results from our tectonic and geomorphological mapping to develop a reconstruction of landscape evolution since the deposition of AF3 TG fan (see Figure 9). We base the timing of our reconstruction on the cosmogenic nuclide surface exposure ages determined in this study. Additionally, we assume that alluvial fans are deposited either during glacial periods with higher sediment production, or at the transition to interglacial periods, when sediment stored behind the mountain front is removed by increasing stream power and deposited downslope (Nottebaum et al., in review; Lehmkuhl et al., 2018). Incision and abandonment of alluvial fans is assumed to occur at the transition to or during interglacial times, when precipitation and stream power increases. We adapt the interpretation by Vassallo et al. (2005) and Vassallo et al. (2007) that glacial-interglacial transitions, and hence, the development of new alluvial fan levels, occur every $100 \mathrm{kyr}$ in the Gobi Altai. In this context, we interpret that the exposure ages determined from cosmogenic nuclide dating also represent the ages of alluvial fan abandonment. For simplification purposes, we assume the age of the AF3 surface to be $400 \mathrm{ka}$, i.e., disregarding its uncertainty. Overall, this reconstruction shows that the deposition of fluvial (and lacustrine) deposits is likely dominated by climate cyclicity, however drainage reorganization is highly susceptible to tectonic activity along the VGL faults.

We assume that the primary step in the evolution of this landscape is the abandonment of alluvial fan AF3 at around $400 \mathrm{ka}$ (see top left frame in Figure 9). Because we observed fluvial pebbles on top of the bedrock ridge west of the Bogd settlement, we interpret that AF3 was abandoned after or during activity of fault F1. No remnants of the AF3 fan are found south of this fault which means that either 1) AF3 was not deposited there, or 2) remnants of AF3 have been covered by more recent deposits south of F1. Fault F2 was active after formation of AF3, and before AF2: this fan remnant is not found downstream (south) of the fault. Assuming a $\sim 100 \mathrm{kyr}$ cyclicity for fan deposition, we tentatively assign an age of $\sim 300 \mathrm{ka}$ to deposit AF2. The regional westward tilt of AF2 close to the Hangay and the overall occurrence of AF2 west of TG, likely reflect autogenic fan processes that prompt random deflections of channel morphology and sediment distribution (e.g., Ventra and Nichols, 2014). Alternatively, they may be the result of tilting due to activity along the Bayankhonghor fault before or during AF2 formation (e.g., Walker et al., 2007). Fault activity along the NW-SE striking components of F1 likely started before AF3 formed; the fault-parallel stream localization of the palaeochannel is strong evidence that these faults were active prior to AF1 deposition. The terrace remnants within the palaeochannel imply that multiple incision events occurred prior to $135 \pm 34 \mathrm{ka}$, and thus, that it was active for an extended period. The interference of $\mathrm{ON}$ beach ridges with the palaeochannel deposits at its outlet to the basin reflect that the channel was active during the MIS 5 lake level highstand (80-130 ka; Lehmkuhl and Lang, 2001; Lehmkuhl et al., 2018a; Nottebaum et al., in review) and prior to the beach ridges that form an erosional scarp south of the palaeochannel. These latter beach ridges may reflect an MIS 3 (i.e., ca. 60-40 ka) lake highstand (Figure 6D; Nottebaum et al., in review), as was dated from a beach ridge with the same elevation in a basin west of $\mathrm{ON}$. With regard to the $\sim 90 \mathrm{ka}{ }^{10} \mathrm{Be}$ inheritance measured from the TG active channel, the palaeochannel could have been active up to MIS 3 or even Holocene times. However, taking into account an MIS 3 age for the erosional scarp that cuts off the most recent palaeochannel deposits, and the occurrence of at least two prior terraces/incision events, we interpret the channel to have been active $\sim 200-50 \mathrm{ka}$. Continued fault activity of F1 and F2 after abandonment of the palaeochannel is confirmed by minor fault scarps that cut across the palaeochannel sediments (Figures 6A,D, respectively). Considering the $0.08 \pm 0.03 \mathrm{~mm} / \mathrm{yr}$ slip rate of F2 estimated from the AF3 surface, the $10.2 \pm 6.2 \mathrm{~m}$ offset measured within the palaeochannel confirms that the scarp developed over $129.0 \pm 91.7 \mathrm{kyr}$. The abandonment of the palaeochannel likely occurred as a result of tectonic activity of faults F1, F2 and possibly F3, along which terrace remnants of AF2 are preserved within AF1. The timing of the subsequent eastward deflection of the Tuyn Gol to its modern channel cannot be constrained, yet the formation of Holboliin Nuur, probably as a result of ponding, indicates that activity along F2 was still ongoing. A high level of Orog Nuur, for example during MIS 3 (Lehmkuhl and Lang, 2001; Lehmkuhl et al., 2018a; Nottebaum et al., in review), could have also played a role in the formation of lakes north of F2: the high base level would have reduced the incentive for the river to incise through the uplifted AF3 surface here. A lowering of the lake level or an increase in stream power would then have allowed for the final incision of the TG channel and deposition of T0, toward its current apex at the Bogd settlement. Considering the trend of alluvial fan abandonment at the transition from glacial to interglacial times (Vassallo et al., 2007), incision and AF0 deposition south of the Bogd settlement and F1 may have occurred after the Last Glacial Maximum (21 ka; Lehmkuhl et al., 2018a). The overprinting of AF0 in the Orog Nuur Basin by mid-Holocene beach ridges (Lehmkuhl et al., 2018; Nottebaum et al., in review) suggests that AF0 had already been deposited at that time. A continued fault activity along F1 is suggested by the narrow gorge that is observed at the Bogd settlement: the outlet of the Tuyn Gol is less than $10 \%$ as wide as the river is further north $(\sim 20 \mathrm{~m}$ vs. $3,500 \mathrm{~m})$. The landscape evolution we suggest indicates that 
there may be a northward movement of the deformation front from fault F1 to F4, which would be in line with a strike-slip regime, and a northward expansion of the Gobi Altai.

The concept of qualitative studies of local landscape dynamics as a function of climatic and tectonic processes allows us not only to understand the interplay between these external factors, but also to evaluate the Middle Pleistocene to modern tectonic activity along fault scarps that have previously been overlooked in the regional structure. We argue that in addition to local tectonic geomorphology studies of historically or instrumentally seismic faults, regional studies of landscape dynamics can be valuable, especially in slowly deforming, seismically quiescent continental interiors.

\section{CONCLUSIONS}

The fault scarps in the VGL play an important role in the accommodation of stresses in southern Mongolia, and our studies show that they should be included in studies of regional active tectonics and landscape evolution.

- Kinematics of the VGL faults reflect the regional strain field and suggest a dominant strike-slip regime that fits with the geometries observed in the Gobi Altai and the Hangay. The reduced localization of faulting is likely due to a difference in underlying crustal structures along which deformation concentrates.

- The VGL faults take up a total of $0.27 \pm 0.08 \mathrm{~mm} / \mathrm{yr}$ vertical slip, which is around the same order of magnitude as is taken up by localized deformation along the Bogd fault $(<0.3 \mathrm{~mm} / \mathrm{yr})$.

- Each of the four faults is long enough to accommodate $\mathrm{M}$ 7 earthquakes, however recurrence intervals of such earthquakes are an order of magnitude longer than the Bogd fault (3-5 kyr) at faults F2-F4 (17.1 $\pm 6.1-81.57 \pm$ $46.05 \mathrm{kyr})$, and at least twice as long at F1 (5.24 $\pm 2.61 \mathrm{kyr})$.

- Landscape reconstructions reflect that tectonic activity has played an important role in the evolution of the TG and the infill of the VGL since $400 \pm 102 \mathrm{ka}$.

We showed that, especially in slow-slip, intraplate regions, where instrumental seismicity is scarce, it is essential to undertake regional scale tectonic geomorphological studies. Additional

\section{REFERENCES}

Anderson, R. S., Repka, J. L., and Dick, G. S. (1996). Explicit treatment of inheritance in dating depositional surfaces using in situ Be-10 and Al-26. Geology. 24 (1), 47-51.

Arrowsmith, J. R., and Zielke, O. (2009). Tectonic geomorphology of the San Andreas Fault zone from high resolution topography: an example from the Cholame segment. Geomorphology. 113 (1-2), 70-81. doi:10.1016/j.geomorph. 2009.01.002

Balco, G., Stone, J. O., Lifton, N. A., and Dunai, T. J. (2008). A complete and easily accessible means of calculating surface exposure ages or erosion rates from Be- dating of palaeo-earthquakes is necessary to determine the seismic hazard of such unknown faults.

\section{DATA AVAILABILITY STATEMENT}

The raw data supporting the conclusion of this article will be made available by the authors, without undue reservation.

\section{AUTHOR CONTRIBUTIONS}

JW acquired, analysed and interpreted the data, prepared the cosmogenic nuclide samples, designed the figures and prepared the manuscript with contribution from the co-authors. VN contributed to the acquisition, discussion and interpretation of data and to the conceptualisation and reviewing of the manuscript. GS contributed to the acquisition, discussion and interpretation of data and to the conceptualisation and reviewing of the manuscript. SB analysed the cosmogenic nuclide samples at the lab in Cologne, contributed to data interpretation, statistical analyses, and reviewing of the manuscript. $\mathrm{OB}$ supported the organisation of field work and data acquisition in Mongolia. FL and KR contributed to the conceptualisation and discussion of the manuscript and acquired funding.

\section{FUNDING}

This project was funded by the German Federal Ministry of Education and Research (BMBF) within the sub-project Q-TiP of research project CAME II (grant 03G0863). TanDEM-X WorldDEM $^{\mathrm{TM}}$ data was acquired by a grant from The German Aerospace Center (DLR) in 2017.

\section{ACKNOWLEDGMENTS}

We thank our colleagues from the Institute of GeographyGeoecology of the Mongolian Academy of Sciences in Ulaanbaatar, who helped organize and carry out the field campaign. A preprint of this research was presented at the EGU General Assembly 2020 (van der Wal et al., 2019). We appreciate the constructive feedback of reviewers R. Jayangonda Perumal and Jian-Cheng Lee and editor Ramon Arrowsmith.
10 and Al-26 measurements. Quat. Geochronol. 3 (3), 174-195. doi:10.1016/j. quageo.2007.12.001

Baljinnyam, I., Bayasgalan, A., Borisov, B. A., Cisternas, A., Dem'yanovich, M. G., Ganbaatar, L., et al. (1993). Ruptures of major earthquakes and active deformation in mongolia and its surroundings. Geol. Soc. Am. Mem. 181, 62. doi:10.1130/MEM181

Bayasgalan, A., Jackson, J., Ritz, J., and Carretier, S. (1999). Forebergs, flower structures, and the development of large intra-continental strike-slip faults: the Gurvan Bogd fault system in Mongolia. J. Struct. Geol. 21, 1285-1302. doi:10. 1016/S0191-8141(99)00064-4

Bevington, P. R., and Robinson, D. K. (2003). Data reduction and error analysis for the physical sciences. Third edition. New York, NY: McGraw-Hill Book Co. 
Binnie, S. A., Dunai, T. J., Voronina, E., Goral, T., Heinze, S., and Dewald, A. (2015). Separation of $\mathrm{Be}$ and $\mathrm{Al}$ for AMS using single-step column chromatography. Nucl. Instrum. Methods B. 361, 397-401. doi:10.1016/j. nimb.2015.03.069

Binnie, S. A., Dewald, A., Heinze, S., Voronina, E., Hein, A., Wittmann, H., et al. (2019). Preliminary results of CoQtz-N: a quartz reference material for terrestrial in-situ cosmogenic ${ }^{10} \mathrm{Be}$ and ${ }^{26} \mathrm{Al}$ measurements. Nucl. Instrum. Methods B. 456, 203-212. doi:10.1016/j.nimb.2019.04.073

Binnie, A., Binnie, S. A., and Partelli, E. J. R. (2020). The implications of sampling approach and geomorphological processes for cosmogenic ${ }^{10} \mathrm{Be}$ exposure dating of marine terraces. Nucl. Instrum. Methods B. 467, 130-139. doi:10.1016/j.nimb. 2019.12.017

Boulton, S. J., and Stokes, M. (2018). Which DEM is best for analyzing fluvial landscape development in mountainous terrains? Geomorphology. 310, 168-187. doi:10.1016/j.geomorph.2018.03.002

Bull, W. B. (2007). Tectonic geomorphology of mountains: a new approach to paleoseismology. Hoboken, NJ: Blackwell publishing. doi:10.1002/ 9780470692318

Burbank, D. W., and Anderson, R. S. (2001). Tectonic geomorphology. Australia: Blackwell Science Ltd., 160. doi:10.1002/gj.2544

Calais, E., Vegnolle, M., San'kov, V., Lukhnev, A., Miroshnitchenko, A., Amarjargal, S., et al. (2003). GPS measurements of crustal deformation in the Baikal-Mongolia area (1994-2002): implications for current kinematics of Asia. J. Geophys. Res.: Solid Earth. 105, B10. doi:10.1029/2002JB002373

Caves, J. K., Sjostrom, D. J., Mix, H. T., Winnick, M. J., and Chamberlain, C. P. (2014). Aridification of central Asia and uplift of the Altai and Hangay mountains, Mongolia: stable isotope evidence. Am. J. Sci. 314 (8), 1171-1201. doi:10.2475/08.2014.01

Clark, D., McPherson, A., Cupper, M., Collins, C. D. N., and Nelson, G. (2015). "The Cadell Fault, southeastern Australia: a record of temporally clustered morphogenic seismicity in a low-strain intraplate region," in Seismicity, fault rupture and earthquake hazards in slowly deforming regions. Editors A. Landgraf, S. Kübler, E. Hintersberger, and S. Stein (London, United Kingdom: Geological Society, London, Special Publications). First published online (November 18, 2015), 432. doi:10. $1144 / \mathrm{SP} 432.2$

Comeau, M. J., Becken, M., Käufl, J. S., Grayver, A. V., Kuvshinov, A. V., Tserendug, S., et al. (2020). Evidence for terrane boundaries and suture zones across Southern Mongolia detected with a 2-dimensional magnetotelluric transect. Earth Planets Space. 72, 5. doi:10.1186/s40623-010-1131-6

Cunningham, W. D. (2005). Active intracontinental transpressional mountain building in the Mongolian Altai: defining a new class of orogeny. Earth Planet Sci. Lett. 240 (2), 436-444. doi:10.1016/j.epsl.2005.09.013

Cunningham, W. D. (2001). Cenozoic normal faulting and regional doming in the southern Hangay region, Central Mongolia: implications for the origin of the Baikal rift province. Tectonophysics. 331, 389-411. doi:10.1016/S0040-1951(00) 00228-6

Cunningham, W. D. (2010). Tectonic setting and structural evolution of the late cenozoic Gobi Altai orogen. Geological Society, London, Special Publications. 338, 361-387. doi:10.1144/SP338.17

Cunningham, W. D. (2013). Mountain building processes in intracontinental oblique deformation belts: lessons from the Gobi Corridor, Central Asia. J. Struct. Geol. 46, 255-282. doi:10.1016/j.jsg.2012.08.010

Cunningham, W. D., Windley, B. F., Owen, L. A., Barry, T., Dorjnamjaa, D., and Badamgarav, J. (1997). Geometry and style of partitioned deformation within a late Cenozoic transpressional zone in the eastern Gobi Altai Mountains, Mongolia. Tectonophysics. 277 (4), 285-306. doi:10.1016/S0040-1951(97) 00034-6

D’Arcy, M. K., Schildgen, T. F., Turowski, J. M., and DiNezio, P. (2019). Inferring the timing of abandonment of aggraded alluvial surfaces dated with cosmogenic nuclides. Earth Surf. Dynam. 7 (3), 755-771. doi:10.5194/esurf-7-755-2019

Dewald, A., Heinze, S., Jolie, J., Zilges, A., Dunai, T., Rethemeyer, J., et al. (2013). CologneAMS, a dedicated center for accelerator mass spectrometry in Germany. Nucl. Instrum. Methods B. 294, 18-23. doi:10.1016/j.nimb.2012. 04.030

Dugarmaa, T. Schlupp, A. Adiya, M. Ankhtsetseg, D. Baasanbat, Ts. Bayar, G., et al. and the DASE/LDG, DASE/TMG teams (2003). Map of 'One century of seismicity in Mongolia (1900-2000)'. Research Centre of Astronomy,
Geophysics of the Mongolian Academy of Sciences (RCAG), Mongolia and Laboratoire de Télédétection et Risque Sismique, BP12. France: Bruyères le Chatel.

Erdenetsogt, B., Lee, I., Bat-Erdene, D., and Jargal, L. (2009). Mongolian coalbearing basins: geological settings, coal characteristics, distribution, and resources. Int. J. Coal Geol. 80 (2), 87-104. doi:10.1016/j.coal.2009.08.002

German Aerospace Center (2017). TanDEM-X WorldDEM ${ }^{\mathrm{TM}}$ data. Proposal ID 'DEM_GEOL1334'.

Heidbach, O., Rajabi, M., Reiter, K., Ziegler, M., and WSM Team (2016). World stress map database release 2016, V. 1.1. GFZ Data Services. doi:10.5880/WSM. 2016.001

Howard, J. P., Cunningham, W. D., and Davies, S. J. (2006). Competing processes of clastic deposition and compartmentalized inversion in an actively evolving transpressional basin, western Mongolia. Journal of the Geophycial Society. 163, 657-670. doi:10.1144/0016-764904-073

Käufl, J. S., Grayver, A. V., Comeau, M. J., Kuvshinov, A. V., Becken, M., Kamm, J., et al. (2020). Magnetotelluric multiscale 3-D inversion reveals crustal and upper mantle structure beneath the Hangai and Gobi-Altai region in Mongolia. Geophys. J. Int. 221 (2), 1002-1028. doi:10.1093/gji/ggaa039

Kohl, C. P., and Nishiizumi, K. (1992). Chemical isolation of quartz for measurement of in situ produced cosmogenic nuclides. Geochim. cosmochim. Acta. 56, 3583-3587.

Komatsu, G., Brantingham, P. J., Olsen, J. W., and Baker, V. R. (2001). Paleoshoreline geomorphology of böön tsagaan nuur, tsagaan nuur and Orog nuur: the Valley of lakes, Mongolia. Geomorphology. 39 (3-4), 83-98. doi:10.1016/S0169-555X(00)00095-7

Kurtz, R., Klinger, Y., Ferry, M., and Ritz, J.-F. (2018). Horizontal surface-slip distribution through several seismic cycles: the Eastern Bogd fault, Gobi-Altai, Mongolia. Tectonophysics. 734-735, 167-182. doi:10.1016/j.tecto.2018.03.011

Kurushin, R. A., Bayasgalan, A., Ölz, M., Enhtuvshin, B., Molnar, P., Bayars, Ch., et al. (1997). The surface rupture of the 1957 gobi-altay, Mongolia, earthquake. New York, NY: The Geological Society of America. Special Paper 320.

Landgraf, A., Kübler, S., Hintersberger, E., and Stein, S. (2015). "Active tectonics, earthquakes and paleoseismicity in slowly deforming continents," in Seismicity, fault rupture and earthquake hazards in slowly deforming regions. Editors A. Landgraf, S. Kübler, E. Hintersberger, and S. Stein (London, United Kingdom: Geological Society, London, Special Publications). First published online (November 18, 2015), 432. doi:10.1144/SP432.13

Lehmkuhl, F., and Lang, A. (2001). Geomorphological investigations and luminescence dating in the southern part of the Khangay and the Valley of the Gobi Lakes (Central Mongolia). J. Quat. Sci. 16 (1), 69-87. doi:10.1002/ 1099-1417(200101)16:1\%3C69::AID-JQS583\%3E3.0.CO;2-O

Lehmkuhl, F., Nottebaum, V., and Hülle, D. (2018). Aspects of late quaternary geomorphological development in the khangai mountains and the Gobi Altai mountains (Mongolia). Geomorphology. 312, 24-39. doi:10.1016/j.geomorph. 2018.03.029

Lehmkuhl, F., Grunert, J., Hülle, D., Batkhishig, O., and Stauch, G. (2018a). Paleolakes in the Gobi region of southern Mongolia. Quat. Sci. Rev. 179, 1-23. doi:10.1016/j.quascirev.2017.10.035

Lifton, N., Sato, T., and Dunai, T. J. (2014). Scaling in situ cosmogenic nuclide production rates using analytical approximations to atmospheric cosmic-ray fluxes. Earth Planet Sci. Lett. 386, 149-160. doi:10.1016/j.epsl.2013.10.052

J. McCalpin (2009). Paleoseismology, in International geophysics series. 2nd Edition (Burlington, MA: Academic Press).

Meltzer, A., Stachnik, J. C., Sodnomsambuu, D., Munkhuu, U., Tsagaan, B., Dashdondog, M., et al. (2019). The Central Mongolia seismic experiment: multiple applications of temporary broadband seismic arrays. Seismol Res. Lett. 90 (3). doi: $10.1785 / 0220180360$

Mosionzd, K. A., Bochkov, S. V., Vertlib, V. N., Basmanov, V. M., and Dobrov, G. M. (1988). Geological map of the Mongolian people's republic., 1:200.000. Irkutsk, Russia: USSR Ministry of Geology, Foreign Geology.

Munkhuu, U. (2018). Personal communication. Ulaanbaatar, Mongolia: Mongolian Academy of Sciences.

Nishiizumi, K., Imamura, M., Caffee, M. W., Southon, J. R., Finkel, R. C., and McAninch, J. (2007). Absolute calibration of Be-10 AMS standards. Nucl. Instrum. Methods B. 258 (2), 403-413. doi:10.1016/j.nimb.2007.01.297

Nottebaum, V., Stauch, G., van der Wal, J. L. N., Zander, A., Reicherter, K., Batkhishig, O., et al. (in review). A late MIS 5 megalake period and sedimentary 
system interactions in the endorheic Orog Nuur Basin during the late quaternary. Earth Surf. Process. Landforms.

Prentice, C. S., Kendrick, K., Berryman, K., Bayasgalan, A., Ritz, J. F., and Spencer, J. Q. (2002). Prehistoric ruptures of the gurvan bulag fault, Gobi altay, Mongolia. J. Geophys. Res.: Solid Earth. 107 (B12), 2321. doi:10.1029/ 2001JB000803

Repka, J. L., Anderson, R. S., and Finkel, R. C. (1997). Cosmogenic dating of fluvial terraces, Fremont River, Utah. Earth Planet Sci. Lett. 152 (1-4), 59-73.

Ritz, J. F., Brown, E. T., Bourlès, D. L., Philip, H., Schlupp, A., Raisbeck, G. M., et al. (1995). Slip rates along active faults estimated with cosmic-ray-exposure dates: application to the Bogd fault, Gobi-Altaï, Mongolia. Geology. 23 (11), 1019-1022.

Ritz, J. F., Vassallo, R., Braucher, R., Brown, E. T., Carretier, S., and Bourlès, D. L. (2006). Using in situ-produced ${ }^{10} \mathrm{Be}$ to quantify active tectonics in the Gurvan Bogd mountain range (Gobi-Altay, Mongolia). Special Paper 303. New York, NY: Geological Society of America, 415, 87-110. doi:10.1130/2006.2415(06)

Rizza, M., Ritz, J. F., Braucher, R., Vassallo, R., Prentice, C., Mahan, S., et al. (2011). Slip rate and slip magnitudes of past earthquakes along the Bogd left-lateral strike-slip fault (Mongolia). Geophys. J. Int. 186 (3), 897-927. doi:10.1111/j. 1365-246X.2011.05075.x

Schlupp, A., and Cisternas, A. (2007). Source history of the 1905 great Mongolian earthquakes (Tsetserleg, Bolnay). Geophys. J. Int. 169, 1115-1131. doi:10.1111/j. 1365-246X.2007.03323.x

Sodnomsambuu, D., and Klyuchevskii, A. V. (2017). Lithospheric stress in Mongolia, from earthquake source data. Geoscience Frontiers. 8, 1323-1337. doi:10.1016/j.gsf.2017.01.003

Tapponnier, P., and Molnar, P. (1979). Active faulting and cenozoic tectonics of the tien Shan, Mongolia, and baykal regions. J. Geophys. Res.: Solid Earth. 84 (B7), 3425-3459. doi:10.1029/JB084iB07p03425

van der Wal, J. L. N., Nottebaum, V. C., Stauch, G., Lehmkuhl, F., and Reicherter, K. (2019). "Geomorphological evidence of active faulting in low seismicity regions-examples from the Valley of Lakes, southern Mongolia," EGU General Assembly 2020, Online, 4-8 May 2020, EGU2020-949. doi:10.5194/ egusphere-egu2020-949

van der Wal, J. L. N., Nottebaum, V. C., Gailleton, B., Stauch, G., Weismüller, C., Batkhishig, O., et al. (2020). Morphotectonics of the northern Bogd fault and implications for Middle Pleistocene to modern uplift rates in southern Mongolia. Geomorphology. 367, 107330. doi:10.1016/j.geomorph.2020.107330

Vassallo, R., Ritz, J. F., Braucher, R., and Carretier, S. (2005). Dating faulted alluvial fans with cosmogenic ${ }^{10} \mathrm{Be}$ in the Gurvan Bogd mountain range (Gobi-Altay, Mongolia): climatic and tectonic implications. Terra. Nova. 17 (3), 278-285. doi:10.1111/j.1365-3121.2005.00612.x

Vassallo, R., Ritz, J. F., Braucher, R., Jolivet, M., Carretier, S., Larroque, C., et al. (2007). Transpressional tectonics and stream terraces of the Gobi-Altay, Mongolia. Tectonics. 26 (5). doi:10.1029/2006TC002081

Vassallo, R., Jolivet, M., Ritz, J-F., Braucher, R., Larroque, C., Sue, C., et al. (2007a). Uplift age and rates of the Gurvan Bogd system (Gobi-Altay) by apatite fission track analysis. Earth Planet Sci. Lett. 259 (3-4), 333-346. doi:10.1016/j.epsl. 2007.04.047

Ventra, D., and Nichols, G. J. (2014). Autogenic dynamics of alluvial fans in endorheic basins: outcrop examples and stratigraphic significance. Sedimentology. 61, 767-791. doi:10.1111/sed.12077

Walker, R. T., Bayasgalan, A., Carson, R., Hazlett, R., McCarthy, L., Mischler, J., et al. (2006). Geomorphology and structure of the Jid right-lateral strike-slip fault in the Mongolian Altay mountains. J. Struct. Geol. 28 (9), 1607-1622. doi:10.1016/j.jsg.2006.04.007

Walker, R. T., Nissen, E., and Bayasgalan, A. (2007). Reinterpretation of the active faulting in central Mongolia. Geology. 35 (8), 759-762. doi:10.1130/G23716A.1

Walker, R. T., Molor, E., Fox, M., and Bayasgalan, A. (2008). Active tectonics of an apparently aseismic region: distributed active strike-slip faulting in the Hangay Mountains of central Mongolia. Geophys. J. Int. 174, 1121-1137. doi:10.1111/j. 1365-246X.2008.03874.x

Walker, R. T., Wegmann, K. W., Bayasgalan, A., Carson, R. J., Elliott, J., Fox, M., et al. (2015). “The Egiin Davaa prehistoric rupture, central Mongolia: a large magnitude normal faulting earthquake on a reactivated fault with little cumulative slip located in a slowly deforming intraplate setting," in Seismicity, fault rupture and earthquake hazards in slowly deforming regions. Editors A. Landgraf, S. Kübler, E. Hintersberger, and S. Stein (London, United Kingdom: Geological Society, London, Special Publications), 432. First published online November 18, 2015. doi:10. $1144 / \mathrm{SP} 432.4$

Walther, M. (1998). Paläoklimatische Untersuchungen zur jungpleistozänen Landschaftsentwicklung im Changai-Bergland und in der nördlichen Gobi (Mongolei). Petermanns Geogr. Mittl. 142 (1998/3+4), 207-217.

Wells, D. L., and Coppersmith, K. J. (1994). New empirical relationships among magnitude, rupture lenght, rupture width, rupture area, and surface displacement. Bull. Seismol. Soc. Am. 84 (4), 974-1002.

Zielke, O., Klinger, Y., and Arrowsmith, R. (2015). Fault slip and earthquake recurrence along strike slip faults - contributions of high-resolution geomorphic data. Tectonophysics. 638, 43-62. doi:10.1016/j.tecto.2014.11.004

Conflict of Interest: The authors declare that the research was conducted in the absence of any commercial or financial relationships that could be construed as a potential conflict of interest.

Copyright $\odot 2021$ van der Wal, Nottebaum, Stauch, Binnie, Batkhishig, Lehmkuhl and Reicherter. This is an open-access article distributed under the terms of the Creative Commons Attribution License (CC BY). The use, distribution or reproduction in other forums is permitted, provided the original author $(s)$ and the copyright owner(s) are credited and that the original publication in this journal is cited, in accordance with accepted academic practice. No use, distribution or reproduction is permitted which does not comply with these terms. 